\title{
How Banks Go Abroad: Branches or Subsidiaries?
}

\author{
Eugenio Cerutti, Giovanni Dell'Ariccia, and Maria Soledad Martínez Pería*
}

\begin{abstract}
This paper examines the factors that influence banks' type of organizational form when operating in foreign markets, using an original database on the branches and subsidiaries in Latin America and Eastern Europe of the top 100 international banks. We find that regulation, taxation, the degree of desired penetration in the local market, and host-country economic and political risks matter. Banks are more likely to operate as branches in countries that have higher corporate taxes and when they face lower regulatory restrictions on bank entry, in general, and on foreign branches, in particular. Subsidiaries are the preferred organizational form by banks that seek to penetrate the local market establishing large and mostly retail operations. Finally, there is evidence that economic and political risks have opposite effects on the type of organizational form, suggesting that legal differences in the degree of parent bank responsibility vis-à-vis branches and subsidiaries under different risk scenarios play an important role in the kind of operations international banks maintain overseas.
\end{abstract}

JEL: F23, G21

Keywords: foreign banks, organizational choice

World Bank Policy Research Working Paper 3753, October 2005

The Policy Research Working Paper Series disseminates the findings of work in progress to encourage the exchange of ideas about development issues. An objective of the series is to get the findings out quickly, even if the presentations are less than fully polished. The papers carry the names of the authors and should be cited accordingly. The findings, interpretations, and conclusions expressed in this paper are entirely those of the authors. They do not necessarily represent the view of the World Bank, its Executive Directors, or the countries they represent. Policy Research Working Papers are available online at http://econ.worldbank.org.

Johns Hopkins University, International Monetary Fund, and World Bank, respectively. We thank Ugo Panizza and researchers at the Inter-American Development Bank for providing us data. We are grateful for comments and suggestions received from Alberto Pozzolo and other participants at the World Bank and Journal of Banking and Finance conference on Globalization and Financial Services in Emerging Economies.

Contact information: Maria Soledad Martínez Pería, World Bank, 1818 H Street, N.W., Washington D.C., 20433. Phone: (202)458-7341. Fax: (202)522-1155. Email addresses: ecerutti@jhu.edu, gdellariccia@imf.org, mmartinezperia@worldbank.org. 


\section{INTRODUCTION}

Over the last two decades, many countries liberalized bank activities that traditionally had been heavily regulated and protected from competition. As part of this process, foreign banks, which had previously played only a marginal role, have established a substantial presence in the banking systems of several middle-income and developing countries. That presence has taken a variety of forms, ranging from the acquisition of domestic institutions with extensive branch networks to the establishment of isolated representative offices aimed at serving niche market segments. However, in contrast to the growing debate on the merits and pitfalls associated with an extensive foreign bank presence in emerging markets, little attention has been paid to how that presence is established. In particular, the literature has largely ignored what determines whether banks operate as locally incorporated and independently capitalized subsidiaries or as branches when going overseas.

In this paper, using a newly put together database on the activities of the top 100 international banks worldwide, we try to fill this gap by examining what factors affect the type of organizational form under which banks operate in foreign markets. We focus on foreign bank operations in Latin America and Eastern Europe, the two regions that have witnessed the largest increase in foreign bank participation over the last decade. In both regions, current levels of foreign bank participation exceed $50 \%$ of banking system assets in many countries.

There are at least two sets of reasons for which policy makers, bank users, and bankers should care about how foreign banks operate in host markets. First, the organizational form of foreign bank operations may affect the competitive structure of the local banking systems, threatening the profits and market share of domestic banks and affecting the price and quality of banking services in the host country. For example, foreign subsidiaries with extensive networks are in direct competition with local commercial banks for retail clients, while single-branch 
foreign banks or representative offices concentrate, instead, on segments such as wholesale and investment banking, which are typically undeveloped in the host countries. Second, branches and subsidiaries typically involve different levels of parent bank responsibility and financial support. While subsidiaries are separate entities from their parent banks, under most circumstances, parent banks are responsible for the liabilities of their branches. ${ }^{1}$ This can have implications not only for the parent bank but also for local regulators, who care about the stability of the hostcountry, and for local depositors, who care about the safety of their savings.

We build an empirical reduced form model that allows banks' organizational form to depend on parent bank characteristics, home-country regulations, the desired level of penetration in the host market (as proxied by affiliate bank characteristics) and host-country factors. Among the parent bank characteristics, we allow parent banks' size, business orientation (wholesale versus retail), degree of international presence, and past expansion strategies to affect foreign banks' organizational form in a given host-country. We measure the desired level of penetration in the host market by controlling for the affiliate size and business orientation.

Among the host-country factors, we consider the impact of legal restrictions on foreign bank operations, entry requirements, and corporate taxes. In addition, we examine whether differences in the degree of legal responsibility by parent banks vis-à-vis the liabilities of their overseas branches and subsidiaries play a role in foreign banks' organizational form. If these differences indeed affect banks' organizational form, branches would tend to be the preferred

\footnotetext{
${ }^{1}$ The recent crisis in Argentina provides us with examples of the different type of behavior of branches and subsidiaries in line with their legal responsibilities regarding their local liabilities. While Citibank announced an increase in the capital of its branch operations in Argentina, it opted for selling its subsidiary (Bansud). Also, in Argentina Credit Agricole decided to cut its losses by letting the government take over its subsidiaries Bersa, Bisel and Suquia. In Eastern Europe, the Bayerische Landesbank gave up its subsidiary, Croatian Rijecka bank, after a trader at the subsidiary incurred huge foreign exchange losses.
} 
organizational form in host countries characterized by relatively higher economic and political risks.

This question is empirically relevant, especially considering that in practice the distinction between branches and subsidiaries in times of crisis may be much more blurred due to special contractual arrangements (such as ring-fencing provisions) and reputational considerations. On the one hand, ring-fencing provisions may limit the losses faced by parent banks when their branches are in trouble. Such provisions generally establish that parent banks are not required to repay the obligations of a foreign branch if the branch faces repayment problems due to extreme circumstances (such as war or civil conflict) or due to certain actions by the host government (e.g., exchange controls, expropriations, etc.). In recent years, a number of banking groups have adopted ring fencing provisions. ${ }^{2}$ On the other hand, concerns about loss of reputation have in certain instances led parent banks to rescue and recapitalize subsidiaries, even if they were not legally forced to do so. ${ }^{3}$

Our findings confirm some of our expectations, but also pose new questions, and challenge some established views. First, regulations and institutional factors appear to have a paramount effect. Foreign banks are less likely to operate as branches in countries that limit their

\footnotetext{
${ }^{2}$ In the case of U.S. bank branches section $25 \mathrm{C}$ of the Federal Reserve Act establishes that "a member bank shall not be required to repay any deposit made at a foreign branch of the bank if the branch cannot repay the deposit due to an act of war, insurrection, or civil strife or (2) an action by a foreign government or instrumentality (whether de jure or de facto) in the country in which the branch is located, unless the member bank has expressly agreed in writing to repay the deposit under those circumstances". Another example of ring fencing provisions are the clauses included in the International Swaps and Derivatives Association (ISDA) Master Agreement. These Ring-Fencing Provisions stipulate that the headquarters will bear no responsibility for transactions made at overseas branches in the case of exchange controls or expropriation (see ISDA (2003), Section 10 (a) Ring-Fencing Agreements).

${ }^{3}$ For example, HSCB injected more than U.S. \$600 millions into its Argentine subsidiary following the crisis in that country (Economist Intelligence Unit Wire, December 16, 2003). Similarly, Portugal's Banco Espiritu Santo injected more capital into its Brazilian subsidiary Banco Boavista Interatlantico, after the latter had to make good on the losses sustained by its mutual funds following the Real's devaluation of January 1999. ABN Amro and KBC promised to make good on any losses to clients arising from an alleged fraud at their Hungarian subsidiary K\&H equities (The Economist, September 2003).
} 
activities and where regulation makes it difficult to establish new banks. Branches are, instead, more common in host countries with high corporate taxes - possibly because of the greater ease allowed by this structure in shifting profits across borders - and in poor countries, perhaps because of fewer market opportunities.

Second, our results suggest that different organizational forms are associated with different degrees of penetration in the host market. Branches are more likely when foreign operations are smaller in size and do not have a retail orientation.

Third, host-country risks matter, and in particular, economic and political risks have opposite effects. Branches are less common in countries with highly risky macroeconomic environments, where parent banks seem to prefer the shield of "hard" limited liability provided by subsidiaries to the "soft" protection of ring-fencing. However, when it comes to risks stemming from possible government intervention and other major political events, parent banks are more likely to operate as branches. This is not necessarily surprising. In view of legal provisions that shield parent banks from the liabilities of their foreign branches in events such as wars, insurrections, or arbitrary actions by foreign governments. Under such circumstances, banks are actually more exposed as subsidiaries, which typically have higher capital and reserve requirements and larger investments in local fixed assets relative to branches.

The literature on banks' organizational form has been scant. Our paper relates to early studies on the operations of international banks during the 1970s-1980s (see Goldberg and Saunders 1980; 1981a, b; Goldberg and Johnson 1990; Miller and Parkhe 1998, among others). However, these studies looked at the determinants of each type of organizational form in isolation and did not take into account banks' decision to enter a given market. 
A more recent body of literature has examined related aspects of the rising foreign bank presence in developing countries. ${ }^{4}$ Several authors have analyzed the factors driving the decision of international banks to establish operations overseas and their choice of location during the 1990s (see, for example, Claessens et al. 2000, Focarelli and Pozzolo 2001, Moshirian 2001, Buch and DeLong 2001, Buch 2000, Galindo, Micco and Serra 2003, Buch 2003, Buch and Lipponer 2004, Wezel 2004, Focarelli and Pozzolo 2006). Also, many studies have focused on the implications of foreign bank presence in developing countries. For example, Claessens et al. (2000), Barajas et al. (2000), Denizer (2000), and Martínez Pería and Mody (2004) study the effects on competition and efficiency in the banking sector. Dages et al. (2000), Peek and Rosengren (2000), and de Haas and Levyveld (2002, 2004) compare the lending behavior of foreign and domestic banks during crises. Berger et al. (2001), Mian (2004), and Clarke et al. (2005) study the consequences on access to finance and cherry picking.

The remainder of the paper is organized as follows. Section II explains the dataset collected on the activities of the top 100 banks and their operations in Eastern Europe and Latin America. Section III presents the empirical methodology pursued in the paper to examine the determinants of foreign banks' type of organizational form. Section IV discusses the empirical results. Section V concludes.

\section{DAtA}

To examine international banks' type of organizational form across countries, we assembled an extensive and original database on the operations of the 100 largest banks in the

\footnotetext{
${ }^{4}$ See Clarke et al. (2003) for a review of this literature.
} 
world (according to the size of their global assets as of December 2002). ${ }^{5}$ In particular, we focus on their presence in Latin America and Eastern Europe. ${ }^{6,7}$

Table 1 lists the top 100 commercial banks in the world, specifies their country of origin, and indicates the type of operations — branch or subsidiary — that these banks have (if any) in Latin America and Eastern Europe. ${ }^{8}$ Also, to establish the degree to which each bank has international operations, we report the number of countries where each bank is present. On average, the top 100 banks have operations in more than 15 countries worldwide. Dutch banks have the highest country average, with operations in more than 38 countries. Also, a clear regional pattern emerges from this table. U.S. and Spanish banks are dominant in the Latin American region. German and Italian banks are the key players in Eastern and Central Europe.

The operations of these 100 banks capture most of the foreign bank activity in the host countries in Latin America and Eastern Europe (Table 2). ${ }^{9}$ We define a foreign subsidiary as a locally incorporated bank with a foreign shareholder who owns at least $50 \%$ of the shares. ${ }^{10}$

\footnotetext{
5 Among the top 100 banks, we did not include banks which were owned (50 percent or more of the shares) by another large bank. For example, Bank Austria Creditanstalt AG and Credit Lyonnais SA were not included in the top 100 list because their main shareholders as of 2002 were Bayerisque Hypo-un Vereisbank AG and Credit Agricole S, both in the top 100 list. The shareholder data structure was obtained from Bankscope.

6 In Latin America, we examine international bank operations in Argentina, Bolivia, Brazil, Chile, Colombia, Ecuador, Mexico, Peru, and Uruguay. In Eastern Europe, we focus on Bulgaria, Croatia, Czech Republic, Estonia, Hungary, Latvia, Lithuania, Poland, Slovenia, Slovak Republic, and Turkey.

${ }^{7}$ While it is possible that our sample selection might introduce certain biases, we believe these are unlikely to be relevant for at least two main reasons. First, since our sample covers the large majority of foreign banks operating in the countries considered, we are confident that limiting our sample to the top 100 banks will have little impact on the findings. Second, focusing on Latin America and Eastern Europe is justified by the fact that foreign presence in other parts of the world (most notably in Asia) has been very small until very recently.

${ }^{8}$ Branches operating in a country as a branch of a top 100 subsidiary incorporated in a developing country were coded as a subsidiary. The top 100 bank is under no legal obligation to honor those branches liabilities in excess of their developing country subsidiary.

${ }^{9}$ We eliminated Colombia from our sample because Colombian legislation does not allow the entry of foreign bank branches.

${ }^{10}$ There were only 5 cases in our sample in which a bank in the top 100 list had an equity participation below 50 percent, so we believe that imposing the 50 percent ownership rule when identifying subsidiaries is not likely to bias our estimations. In other words, our sample does not exclude many cases of equity participations below the criteria used to identify subsidiaries.
} 
Branches are, instead, not independently incorporated and fully owned by their foreign parent bank.

Foreign-owned banks represent about 50 percent of the total number of banks in Latin America and Eastern and Central Europe. Those included in our sample capture more than 80 percent of the assets controlled by all foreign banks, on average, across countries. Hungary, Peru and Bolivia are the exception, where the foreign banks in our sample account for less than 60 percent of the assets of the foreign banks in the system, mainly because the biggest foreign banks in these countries are owned by banks from neighboring countries that are not among the world's top 100 banks. ${ }^{11}$ Overall, we capture 247 out of 387 foreign controlled institutions or about 65 percent of the foreign operations in the countries in our sample.

Among the banks in our sample with operations in Latin America and/or in Eastern Europe, there seems to be a preference for subsidiaries (Table 2), which account for $65 \%$ of the number of foreign bank operations in Latin America and for $82 \%$ of those in Eastern Europe.

The operations of the top 100 banks by country of origin (or home-country) are shown in Table 3. It is clear that U.S., German, and Japanese banks are dominant both in terms of assets and number of institutions. There are 20 U.S. banks, 16 German banks, and 11 Japanese banks in the top 100 list. Regarding our sample of host countries, we observe that U.S. and German banks have operations in 15 out of the 20 host countries we consider. Italian and Dutch banks operate in 14 and 12 countries, respectively. The actual number of branches and subsidiaries in the hostcountries that make up our sample can also be observed in Table 2. U.S. banks have 26 subsidiaries and 24 branches, followed by German banks with 42 subsidiaries and 6 branches.

\footnotetext{
${ }^{11}$ Peru's low share data is more subtle and it is due to the importance of Banco de Crédito del Peru and Interbank's shareholders which are companies from Bermudas and Bahamas respectively.
} 
Home- and host-country laws and regulations governing the activities of the affiliates of parent banks are likely to affect banks' organizational form. A dummy summarizing homecountry regulation regarding the operations of their bank affiliates overseas is shown in the last column of Table 3. A value of 1 is associated with countries that place additional restrictions on opening branches relative to subsidiaries. For example, Canadian and Italian banks cannot open a branch without the previous approval of the home regulator. ${ }^{12}$ Also, the Spanish regulator can refuse a bank's application to open an overseas branch based on a wider set of criteria (e.g. legal or other type of obstacles that prevent or hamper the control and inspection of the branch by the home regulator) than in the case of opening a subsidiary.

A summary of the regulatory treatment of branches versus subsidiaries by host regulators is shown in Table 4. Since there are more differences in host-country requirements for foreign branches and subsidiaries than in home-country regulations, we distinguish between four categories of requirements that we later combine into the Host-Country Regulation Index. In particular, we take into account the following separate requirements or restrictions: Written Statements, Restrictions on Activities, Responsibilities Undertaken, and Other Restrictions. A value of one is associated with each category, where the host-country establishes more requirements for opening a foreign branch than for a foreign controlled subsidiary. The most common additional requirements are: the approval of the home-country foreign bank regulator, restrictions for some type of operations (e.g. mortgage transactions) or for operating with hostcountry residents, and a statement of the applicant foreign bank that it will satisfy all claims of the branch that may arise.

\footnotetext{
12 Italian legislation does not include EU Member States on this issue.
} 
Among the host countries in our sample, regulations for Croatia, Hungary, and Poland discriminate the most against foreign branches. Most notably, the first two countries place restrictions on the type of activities that branches can undertake relative to subsidiaries. With the exception of Mexico (where branches can only operate with non-residents), such restrictions appear to be uncommon in Latin America.

\section{EMPIRICAL METHODOLOGY}

We model a bank's organizational form according to equation (1) below:

Organizational Form $_{i, j, k}=\alpha_{0}+\beta_{1}$ Parent Bank Characteristics $i_{i, j}+$ $\beta_{2}$ Home-Country Regulations $_{j}+\beta_{3}$ Affiliate Bank Characteristics $i_{i, j, k}+$ $\beta_{4}$ Host-Country Factors ${ }_{k}+\varepsilon_{i, j, k}$

where Organizational Form ${ }_{i, j, k}$ is a dummy equal to 1 if parent bank i from home-country $\mathrm{j}$ has a branch in host-country $\mathrm{k}$, and 0 if it operates a subsidiary in that country.

Among the Parent Bank Characteristics we control for the size, business orientation and international strategy of each parent bank. Parent Bank Size refers to the log of the total parent bank assets. This data comes from Bankscope. Parent Bank Business Orientation is a dummy that equals one if the bank has a retail orientation and zero if the bank is primarily engaged in wholesale or investment bank activities. The sources for this classification are Bankscope and the home banks' WebPages. Parent Bank Internationalization Strategy refers to the ratio of branches to total foreign operations that the parent bank owns. This variable helps determine whether the 
parent has a clear preference for one type of organizational form or the other. The Bankers' Almanac is the source used to construct this variable.

Home-Country Regulations refers to restrictions placed by home regulators from country j on parent banks' organizational form. In particular, it measures restrictions to open branches relative to subsidiaries. This dummy was constructed on the basis of the information gathered from laws and regulations in the parent countries. More details on this dummy can be seen in Table 3.

We also control for several characteristics of the affiliate bank. Affiliate Bank Size refers to the size of the local affiliate in the host-country, as measured by the number of employees. ${ }^{13}$ This data comes mainly from Bankscope and Bankers' Almanac. Affiliate Bank Business Orientation is a dummy equal to 1 if the affiliate bank has a retail business orientation. The dummy is zero in the case of trade finance and corporative and investment banks. This data come from Bankscope, Bankers' Almanac and individual banks' WebPages. We also include a dummy (labeled Acquisition Dummy) for whether the bank is a greenfield operation (0) or the result of an acquisition (1). Finally, we control for the year in which the affiliate was established (Year-ofentry). Information to construct both of these variables was obtained from numerous sources such as central banks, banks WebPages, Bankers’ Almanac and Bankscope.

Host-Country Factors include measures of banking regulations, corporate taxation, country size, level of development and risk. Among the host country banking regulations, HostCountry Bank Entry Requirements is an index that takes values from 0 to 8, depending on the number of legal submissions required to obtain a license to operate as a bank in the host-country.

\footnotetext{
${ }^{13}$ We use size as measured by employees because data on assets for branches was lacking in many cases given that balance sheets are typically consolidated at the parent level.
} 
These requirements may include none, all or some of the following: (1) draft by laws, (2) intended organizational chart, (3) first 3-year financial projections, (4) financial information on main potential shareholders, (5) background/experience of future directors, (6) background experience of future managers, (7) sources of funds to capitalize new bank and (8) intended differentiation of new bank from others. This index is constructed using the data collected and methodology proposed by Barth, Caprio, and Levine (2001).

Host-Country Restrictions on Bank Activities is also an index developed by Barth et al. (2001). This index, ranging between 1 to 16 , tries to capture the extent to which banks can engage in (a) the business of securities underwriting, brokering, dealing, and all aspects of the mutual fund industry, (b) insurance underwriting and selling, (c) real estate investment, development and management, and (d) whether banks can own non-financial firms. For each of these subcategories, a value between 1 and 4 is assigned depending on whether the activity is unrestricted (1), permitted (2), restricted (3), or prohibited (4).

Host-Country Regulations on Foreign Bank Branches refers to an index that captures the degree to which the host-country restricts the operation of foreign banks as branches in the country, relative to its treatment of foreign subsidiaries. This variable was constructed on the basis of 2002 bank regulations and legislation in each of the twenty host countries. Details on this index are shown on Table 4.

Host-Country Corporate Taxes refers to the top corporate tax rate in the host-country as reported by the Heritage Foundation. Host-Country Size is measured by the log of constant dollar GDP in the host-country. This variable is intended to capture the scope for scale economies in the country. Host-Country GDP per capita, measured as the dollar GDP per capita, is included to capture the degree of economic development in the host-country. This variable may also help to 
measure business opportunities in the host-country. Data for both of these variables comes from the World Development Indicators produced by the World Bank.

Host-Country Risk refers to four different types of host-country risk indexes reported by the International Country Risk Guide (ICRG in its country risk index. ${ }^{14}$ ). These variables are Economic Risk, Political Risk, Investment Profile Risk, and Country Risk (composite index). The Economic Risk rating assesses a country's economic strength or weakness as a function of variables such as the country's GDP per capita, real GDP growth, annual inflation rate, budget balance, and current account balance. ${ }^{15}$ The Political Risk rating provides a summary of the degree of political stability in each host country. Investment Profile Risk, a subcomponent of the Political Risk index, takes into account factors such as contract viability, profits repatriation, payments delays measurements, etc. that affect those who invest in the host country. Finally, the Country Risk is a composite index that includes both economic and political risk variables and other variables such as exchange rate stability and total foreign debt as percent of GDP. We change the sign on these variables from how ICRG reports them, so that higher values indicate greater potential risk.

The type of organizational form explained by equation (1) can only be observed for a given host-country once the parent bank decides to establish operations in that country. Thus, in estimating equation (1) there might be a selection bias, unless we also consider how parent banks make decisions on where to establish foreign operations. We take this into account by estimating a Heckman probit model where the first stage or selection equation is modeled following

\footnotetext{
${ }^{14}$ This index is defined by ICRG so that higher values mean less risk, but in our estimations we reverse the sign on this variable to give it the more intuitive interpretation that higher values mean more risk.

15 Although the ICRG Economic Risk index includes the host-country GDP per capita as a subcomponent, the correlation coefficient between the ICRG Economic Risk index and host-country GDP per capita variables is very low in our sample.
} 
equation (2) below and the second stage is equivalent to the model presented in equation (1) above. $^{16}$

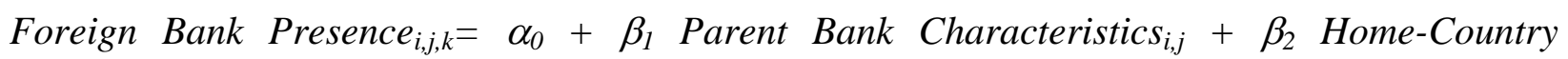

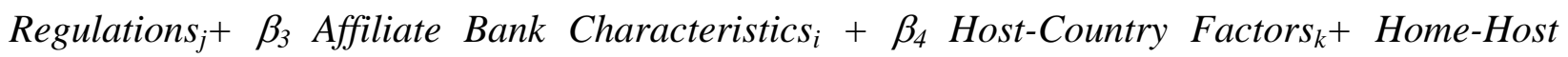
Proximity $_{j, k}+\varepsilon_{i, j, k}$

where Foreign Bank Presence $e_{\mathrm{i}, \mathrm{j}, \mathrm{k}}$ is a dummy equal to 1 if parent bank $\mathrm{i}$ from home-country $\mathrm{j}$ has any kind of operations in host-country $\mathrm{k}$, and 0 if it does not have a presence in the host-country. Most variables included in equation (2) have been defined above, with the following three exceptions. First, within the parent bank characteristics, Parent Bank Worldwide Activity takes into account the number of countries worldwide where each parent bank has activities (data source: Bankers' Almanac). Second, among the regulatory variables, Host-Country (inward) Foreign Investment Regulation and Home-Country (outward) Foreign Investment Regulation capture government controls on inward and outward direct investment in banking, respectively. Both variables are constructed as a five year average (2002-1998) from original IMF data. ${ }^{17}$ Finally, Home-Host Proximity is a matrix of variables that capture the degree of economic, cultural, and institutional affinity between the home and host countries. In particular, it includes separate dummies for whether the host and home-country share (i) a common language and (ii) a

\footnotetext{
${ }^{16}$ An alternative approach would be to estimate a nested logit model where the first decision level is to enter a country or not and the second is whether to operate as a branch or as a subsidiary. The problem with this approach is that we could not study the impact of affiliate characteristics on the second level decision because these factors are not observed for cases when a bank has no operations in a given host. Despite of this limitation, results on the remaining variables, available upon request, yielded very similar findings to those reported here.

${ }^{17}$ The original IMF data are dummies which equal 1 in those years when the countries had controls.
} 
common legal origin. Also, the matrix includes the share of bilateral trade between countries and a measure of geographical distance between home and host countries, measured in miles. We also included a dummy for whether the home and host where in a colonial relationship or colonized by the same country. All these variables come from the Central Intelligence Agency (CIA) World Factbook. ${ }^{18}$

\section{RESULTS}

Table 5 reports the results for the probit estimation of equation $1 .{ }^{19}$ We present six alternative specifications including different proxies for political and economic risk. All regressions are estimated with robust standard errors allowing for the possibility that observations for the same parent bank may not be independent (i.e., we allow for clustered standard errors within parent banks).

Most coefficients are significant and have the expected sign. Since results are robust across specifications, in what follows we focus on our baseline regression labeled model (4).

The results can be summarized as follows. First, regulations matter. The variables describing host- and home-country restrictions on foreign branches both have the expected negative sign and are significant in all specification (often at the 1 percent level), indicating that more restrictions on branches lower the probability that banks adopt this organizational form. Host-

\footnotetext{
${ }^{18}$ The variables included in the first stage equation (or equation (2) above) of the Heckman model that are not included in the equation for the organization form (equation (1)) are the exclusion restrictions which allow identification of the Heckman probit model. We tried a number of variations on these, and results remained largely unchanged. Furthermore, in separate probit estimations, available upon request, we verified that those variables included in the selection equation did not affect the second stage equation (i.e., the type of organizational form).

${ }^{19}$ Note the sample size, which captures the number of bank affiliates (both branches and subsidiaries) drops to 240 observations instead of 247 as shown in table 2, because of missing data for 5 Brazilian banks (all investment banks), one Mexican, and one Polish.
} 
country bank entry requirements, which capture the number of procedures required to license a bank, also have a negative, although less consistently significant, effect on the establishment of branches. One possible explanation for this result is that while branches are typically de-novo operations, banks can circumvent entry requirements by setting up subsidiaries through the purchase of domestic institutions. Consistent with this interpretation, we find that the acquisition dummy is always significant and has a negative sign. ${ }^{20}$ Host-country restrictions on bank activities do not seem, instead, to have a significant impact on the organizational form adopted by foreign banks. This is not necessarily surprising since these restrictions typically apply to both locally- and foreign-incorporated banks.

Second, taxation matters. The coefficient of the host-country top corporate tax rate is positive and highly significant in all regressions. Thus, branches - having an advantage in shifting profits across border - are more likely in countries with relatively higher corporate taxes.

Third, risk matters; suggesting that differences in parent banks' responsibility for the liabilities of branches and subsidiaries play an important role in the organizational form of the affiliates. Under normal circumstances, parents face full responsibility vis-à-vis the liabilities of branches, but their exposure is limited to the loss of the equity invested in the case of subsidiaries. Consistent with these differences in the legal treatment, we find that banks are more likely to operate as branches in host-countries characterized by relatively low economic risk. The coefficient of the proxy for economic risk is negative and significant, suggesting that, in countries with a highly risky macroeconomic environment, parent banks prefer the shield of

\footnotetext{
${ }^{20} \mathrm{We}$ also attempted to look at this hypothesis by adding an interaction term between entry restrictions and the acquisition dummy but, due to multicollinearity with the individual variables that make up the interaction term, this interaction term had to be dropped. Nevertheless, we thank Alberto Pozzolo for the suggestion.
} 
"hard" limited liability provided by subsidiaries to the "soft" protection of ring-fencing. However, the coefficients on the political risk proxy and on the measure of investment risk (capturing risk to the viability of contracts, the risk of expropriation, and potential obstacles to the repatriation of profits), are instead positive and significant, although to a lesser extent. This suggests that when it comes to risks stemming from possible government intervention and other major political events (such as civil unrest or wars), parent banks prefer to operate as branches, since the latter are often protected against such events by ring fencing provisions. ${ }^{21,22}$ In other words, in view of legal provisions that shield parent banks from the liabilities of their foreign branches in events such as wars, insurrections, or actions by foreign governments, banks are in such occasions less exposed as branches than as subsidiaries, which typically have higher capital and reserve requirements and larger investments in local fixed assets.

Fourth, size matters. Our results suggest that different organizational forms are associated with different degrees of penetration in a foreign market on the part of the parent bank. Branches are more likely when foreign operations are smaller in size. The link between the degree of penetration and a lower probability of being a branch is reinforced by the negative and significant coefficient of the dummy indicating that the affiliate is a retail bank. The coefficient of affiliate year-of-entry is positive and significant, suggesting that there has been a recent trend by foreign banks to increasingly penetrate emerging markets by operating as subsidiaries.

A related finding is that branches are less likely in relatively richer countries: the hostcountry's per capita income has a negative and significant coefficient. This may in part reflect

${ }^{21}$ The opposite sign associated with economic and political risk explains why the ICRG country composite risk index in model (1) is not significant.

${ }^{22} \mathrm{We}$ also tried looking at the interaction of affiliate size and political risk but we could not add this variable due to multicollinearity with the individual variables which make up this interaction term that are already included in the regressions. This is due to the fact that while the variability in affiliate size is significant, the same is not true for our measure of political risk, so that the interaction term is highly collinear with size. 
the fact that subsidiaries are often the result of crisis-related acquisitions which are more likely to occur in poorer countries. However, this cannot be the entire story as major crises have occurred also in relatively richer emerging market economies. One additional explanation may be that foreign banks enter as subsidiaries in markets where they believe there is ample room for expansion, and these are typically poorer economies where the local banks are less developed and capitalized, and hence easier to compete against.

Finally, one additional result worth noting is that: parent banks seem to specialize, at least to some extent, in one organizational form or the other, beyond what is explained by their homecountry regulation. Indeed, the worldwide ratio of branches-to-subsidiaries at the parent bank is positive and highly significant. One possible explanation for this finding is that the two organizational forms require different expertise and corporate governance design at the parent level. However, the coefficients of the dummy indicating that the parent institution is a retail bank and that of its size are not significant, suggesting that the business orientation and overall size of the parent bank itself are not important when it comes to the organizational form of its foreign operations. ${ }^{23}$ Possibly, the reason why parent size seems not to matter can be ascribed to the fact that all parent banks in our sample are pretty large, with assets ranging from USD \$1,097,190 millions (Citigroup Inc) to USD\$94,325 millions (Bank of China, Hong Kong).

In Table 6, we measure the economic impact of a change in our explanatory variables by considering what happens to the predicted probability of the affiliate being a branch when each right hand side variable increases from its sample average by one standard deviation (for the dummy variables we consider a change from 0 to 1 ). Among the taxation and regulatory

\footnotetext{
${ }^{23}$ The lack of significance of the parent bank size is another reason why we think that limiting our sample to the 100 top largest banks in the world is not likely to be introducing a bias in our estimations.
} 
variables, corporate taxes, and restrictions on foreign branches in the host-country have the largest impact: a one-standard-deviation increase (decrease) from the average in corporate taxes (restrictions on branches) increases the likelihood that the foreign bank will operate as a branch by about 3.5 percentage points. The economic effect of the other regulatory variables is around 1.5 percentage points. Among the bank-specific factors, the affiliate bank size has the largest impact: a one-standard-deviation increase in affiliate size reduces the likelihood that the affiliate will be a branch by almost 6 percentage points. Year-of-entry and the acquisition dummy are also important with impacts around 4.5 percentage points. In particular, an increase in both variables (by one standard deviation in the first case and from 0 to 1 in the case of the acquisition dummy) lowers the likelihood that the affiliate will be a branch by 4.5 percentage points. Finally, the relative importance of country risk is comparable to that of regulations, with impacts at about 4.3 and 3.2 percentage points for the political risk and the economic risk measures, respectively. A one-standard-deviation increase in political risk raises the likelihood that the foreign affiliate will operate as a branch by 4.3 percentage points, while a one-standard-deviation increase in economic risk, lowers this probability by 3.2 percentage points.

Results for the Heckman probit estimation are shown in Tables 7 and 8. Table 7 shows the first stage of the Heckman estimation, where we model the decision of banks to operate/have a presence in a given host-country (this corresponds to the model labeled equation (2) above). Our estimations yield results consistent with many of the previous studies on this issue, but also offer some new insights. In particular, we show that banks are less likely to have operations in countries where political risk is high. Also, once we control for the market opportunities in the host-country, economic risk does not seem to matter if we do not control for political risk and it is positive when we control for the latter. We interpret the positive coefficient on economic risk 
to be associated with the fact that much of the recent foreign bank entry has occurred following economic crises in the host countries, since these events provide opportunities for "good deals" in terms of acquiring local banks. Finally, like previous studies we find that regulation and taxation have a negative impact on foreign bank presence, while economic and cultural proximity to the host promote presence.

Table 8 shows the results for second stage in the Heckman model, i.e., the likelihood of a parent bank choosing to operate as a branch. These results are very similar (and almost identical in terms of significance) to those for the simple probit model without controlling for sample selection. Therefore, for the sake of brevity, they are not discussed here. Furthermore, the tests of independence of the first (selection) and second stage equations reported at the bottom of Table 8

reveal that we can accept the null of independence, which means that we can take the probit results to be consistent and not affected by selection bias. This also explains why the Heckman second stage results are almost identical to those obtained in the probit estimations shown on Table 5 .

\section{Conclusions}

Our study of the determinants of foreign banks' organizational form yielded three main findings. First, there is evidence that political and economic risk matters for how banks enter new markets, suggesting that the different degree of parent bank responsibility vis-à-vis the liabilities of branches and subsidiaries plays an important role in the decision. Second, different organizational forms correspond to different degrees of penetration by a parent bank to a foreign market. Third, factors such as home- and host-country regulation and taxation also matter. 
From a policy perspective, our results point to two main conclusions. First, since risk matters, parent banks should be expected to behave differently vis-à-vis branches and subsidiaries in times of economic and political crisis. Second, since regulatory variables have non-marginal effects on the form of foreign bank entry, governments can design regulations to favor one structure rather than another. Policy makers concerned with the behavior of foreign banks during periods of financial distress may want to favor branches to tap into the deep pockets of their parents. However, the results indicate that subsidiaries are more likely to enter retail markets and establish large local networks. Hence, a trade-off emerges. While favoring branches may be optimal from the point of view of systemic economic risk management, regulation discouraging foreign banks from establishing local subsidiaries may limit the benefits of foreign bank operations. We leave the analysis of this trade-off to future research. 


\section{References}

Barajas, A., Steiner, R., Salazar N., 2000. The Impact of Liberalization and Foreign Investment in Colombia’s Financial Sector. Journal of Development Economics v63, n1, 157-96.

Barth, J., Caprio, G. and Levine, R., 2001. The Regulation and Supervision of Banks around the World: A New Database. Policy Research Working Paper No. 2588. World Bank: Washington, D.C.

Berger, A., Klapper L., and Udell G., 2001. The Ability of Banks to Lend to Informationally Opaque Small Businesses. Journal of Banking and Finance 25 (12): 2127-2167.

Buch, C., 2000. Why Do Banks Go Abroad? Evidence from German Banks. Financial Markets, Institutions, and Instruments 9, 33-67.

Buch, C., 2003. Information or Regulation: What Drives the International Activities of Commercial Banks? Journal of Money, Credit and Banking 35(6): 851-869.

Buch, C. and DeLong, G., 2001. Cross-Border Bank Mergers: What Lures the Rare Animal? Kiel Institute of World Economics Working Paper No. 1070.

Buch, C. and Lipponer, A., 2004. FDI Versus Cross-border Financial Services: The Globalization of German Banks. Deutsche Bundesbank Discussion Paper - Series 1 $05 / 2004$.

Claessens, S., Demirgüç-Kunt, A., Huizinga, H., 2000. How Does Foreign Entry Affect Domestic Banking Markets? Journal of Banking and Finance v25. n5, 891-911.

Clarke, G., Cull, R., Martínez Pería, M. and Sánchez, S., 2003. Foreign Bank Entry: Experience, Implications for Developing Countries, and Agenda for Further Research. World Bank Research Observer, 18 (1): 25-40.

Clarke, G., Cull, R., Martínez Pería, M., and Sánchez, S., 2005. Bank Lending to Small 
Businesses in Latin America: Does Bank Origin Matter? Journal of Money, Credit, and Banking 37(1), 83-118.

Crystal, J., Dages, B. G., Goldberg, L. B., 2001. Does Foreign Ownership Contribute to Sounder Banks in Emerging Markets? The Latin American Experience, in Litan, R., Masson, P., Pomerleano, M. (Eds.), Open Doors: Foreign Participation in Financial Systems in Developing Countries. Brookings Press, Washington, D.C., 217-266.

Dages, B. G., Goldberg, L. B., Kinney, D., 2000. Foreign and Domestic Bank Participation in Emerging Markets: Lessons from Mexico and Argentina. Federal Reserve Bank of New York Economic Policy Review, 17-36.

Denizer, C., 2000. Foreign Entry in Turkey's Banking Sector, 1980-1997, in Claessens, S., Jansen, M. (Eds.), The Internationalization of Financial Services: Issues and Lessons for Developing Countries. Kluwer Academic, Boston,. 389-406.

Focarelli, D. and Pozzolo, A., 2001. The Patterns of Cross-Border Bank Mergers and Shareholdings in OECD Countries. Journal of Banking and Finance, Vol. 25, No. 12, $2305-2337$.

Focarelli, D. and Pozzolo, A., 2006. Where Do Banks Expand Abroad? An Empirical Analysis. Journal of Business, Vol. 79, No. 1.

Galindo, A., Micco A., and Serra, C., 2003. Better the Devil That You Know:

Evidence on Entry Costs Faced By Foreign Banks, Inter.-American Development Bank Working Paper No. 477.

Goldberg, L. G., Johnson, D., 1990. The Determinants of U.S. Banking Activity Abroad. Journal of International Money and Finance 9, 123-37.

Goldberg, L.G., Saunders, A., 1980. The Causes of U.S. Bank Expansion Overseas: The Case of 
Great Britain. Journal of Money, Credit, and Banking 12, 630-43.

Goldberg, L. G., Saunders, A., 1981a. The Determinants of Foreign Banking Activity in the United States. Journal of Banking and Finance 5, 17-32.

Goldberg, L. G., Saunders, A., 1981b. The Growth of Organizational Forms of Foreign Banks in Haas, de, R. and van Lelyveld, I., 2002. Foreign Bank Penetration and Private Sector Credit in Central and Eastern Europe. De Nederlandsche Bank Staff Reports No. 91.

Haas, de, R. and van Lelyveld, I., 2004. Foreign Banks and Credit Stability in Central and Eastern Europe: A Panel Data Analysis. De Nederlandsche Bank Staff Reports No. 109. Heritage Foundation. Index of Economic Freedom. Washington, DC: Heritage Foundation Press. Martínez Pería, M. and Mody, A., 2004. How Foreign Participation and Market Concentration Impact Bank Spreads: Evidence from Latin America. Journal of Money, Credit, and Banking, 36(3): 511-539.

Mian, A., 2004. Distance Constraints: The Limits of Foreign Lending in Poor Economies. Journal of Finance. Forthcoming.

Miller, S., and Parkhe, A., 1998. Patterns in the Expansion of U.S. Banks' Foreign Operations. Journal of International Business Studies 29 (2): 359-90.

Moshirian, F., 2001. International Investment in Financial Services, Journal of Banking and Finance 25: 317-337.

Peek, J., Rosengren, E.S., 2000. Implications of the Globalization of the Banking Sector: The Latin American Experience. Federal Reserve Bank of Boston, New England Economic Review, 45-62.

Wezel, T., 2004. Foreign Bank Entry into Emerging Economies: An Empirical Assessment of the Determinants and Risks Predicated on German FDI Data. Deutsche 
Bundesbank Discussion Paper - Series 1 01/2004. 
Table 1 - Top 100 International Commercial Banks and Their Operations in Eastern Europe and Latin America, 2002

\begin{tabular}{|c|c|c|c|c|c|c|c|c|c|c|c|c|c|c|c|c|c|c|c|c|c|c|c|}
\hline 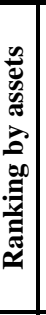 & Parent bank names & 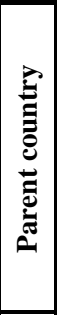 & 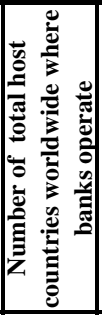 & 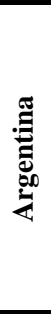 & فำ & 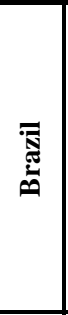 & 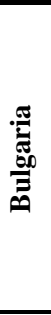 & پِّ & $\begin{array}{l}\frac{\pi}{\partial} \\
\frac{0}{0} \\
\frac{0}{0}\end{array}$ & 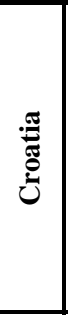 & 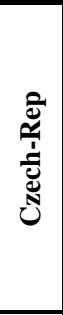 & 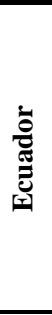 & 营 & 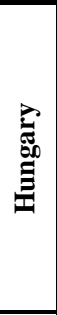 & 莺 & 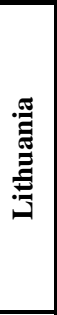 & 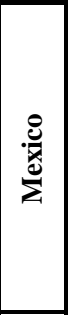 & ت્ّه & 를 & 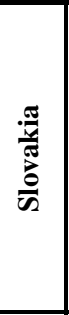 & 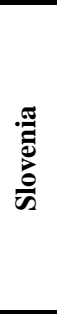 & 总 & 总 \\
\hline 1 & Citigroup Inc & US & 78 & B & B & $\mathrm{B}, \mathrm{S}$ & B & B & $\mathrm{s}$ & & $\mathrm{s}$ & B & & $\mathrm{s}$ & & & $\mathrm{s}$ & B & $\mathrm{S}$ & $\mathrm{S}$ & & B & B \\
\hline 2 & Mizuho Financial Group & $\mathrm{JP}$ & 25 & & & & & & & & & & & & & & & & & & & & \\
\hline 3 & UBS AG & $\mathrm{CH}$ & 28 & & & $\mathrm{~s}$ & & & & & & & & & & & & & & & & & \\
\hline 4 & Sumitomo Mitsui & $\mathrm{JP}$ & 16 & & & $\mathrm{~S}$ & & & & & & & & & & & & & & & & & \\
\hline 5 & Deutsche Bank AG & $\mathrm{DE}$ & 48 & $\mathrm{~s}$ & & $\mathrm{~S}$ & & $\mathrm{~s}$ & & & B & & & $\mathrm{s}$ & & & B & & S (2) & & & & $S(2)^{(a)}$ \\
\hline 6 & Mitsubishi Tokyo Fin. Group & $\mathrm{JP}$ & 33 & $\mathrm{~B}$ & & $\mathrm{~S}$ & & $\mathrm{~B}$ & & & & & & & & & $\mathrm{~B}$ & & $\mathrm{~s}$ & & & & \\
\hline 7 & J.P. Morgan Chase \& Co. & US & 50 & B & & $\mathrm{B}, \mathrm{S}$ & & B & & & & & & & & & B & & - & & & B & \\
\hline 8 & HSBC Holdings Plc & $\mathrm{UK}$ & 63 & $\mathrm{~S}$ & & $\mathrm{~S}(2)$ & & $\mathrm{B}$ & & & B & & & & & $\mathrm{S}^{\text {(a) }}$ & $\mathrm{S}(2)$ & & & & & $\mathrm{S}$ & $\mathrm{S}$ \\
\hline 9 & ING Group NV & $\mathrm{NL}$ & 37 & $\mathrm{~B}$ & & $\mathrm{~B}$ & B & & & & $\mathrm{B}$ & & & $\mathrm{s}$ & & & $\mathrm{B}$ & & $\mathrm{s}$ & $\mathrm{B}$ & & $\mathrm{B}$ & \\
\hline 10 & BNP Paribas & FR & 48 & $\mathrm{~B}, \mathrm{~S}$ & & $\mathrm{~S}$ & $\mathrm{~S}$ & & & & & & & $\mathrm{~S}$ & & & & $\mathrm{~s}$ & $\mathrm{~S}$ & & & & $\mathrm{~s}$ \\
\hline 11 & Credit Suisse Group & $\mathrm{CH}$ & 33 & & & $S(2)$ & & & & & & & & & & & $\mathrm{B}$ & & & & & $\mathrm{B}$ & \\
\hline 12 & Bank Of America & US & 30 & $\mathrm{~B}$ & & $\mathrm{~s}$ & & & & & & & & & & & $\mathrm{~B}$ & & $\mathrm{~S}$ & & & & \\
\hline 13 & Royal Bank of Scotland & $\mathrm{UK}$ & 19 & & & & & & & & & & & & & & & & & & & & 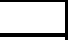 \\
\hline 14 & UFJ Holdings Inc & $\mathrm{JP}$ & 17 & & & & & & & & & & & & & & & & & & & & 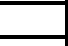 \\
\hline 15 & Barclays Holding Plc & $\mathrm{UK}$ & 41 & & & $\mathrm{~s}$ & & & & & & & & & & & & & & & & & - \\
\hline 16 & Credit Agricole CA & FR & 47 & & & $\mathrm{~S}$ & & & & & $\mathrm{~s}$ & & & $\mathrm{~s}$ & & & & & $\mathrm{~S}(2)$ & $\mathrm{s}$ & & $\mathrm{B}, \mathrm{S}$ & $\mathrm{S}(2)$ \\
\hline 17 & ABN AMRO Bank & $\mathrm{NL}$ & 59 & B & & $\mathrm{S}(2)$ & & $\mathrm{s}$ & $\mathrm{s}$ & & $\mathrm{B}$ & & & & & & $\mathrm{B}$ & & $\mathrm{s}$ & & & $\mathrm{B}$ & $\mathrm{B}$ \\
\hline 18 & Industrial \& Com. Bank of China & $\mathrm{CN}$ & 8 & & & & & & & & & & & & & & & & & & & & \\
\hline 19 & HBOS Plc & $\mathrm{UK}$ & 9 & & & & & & & & & & & & & & & & & & & & \\
\hline 20 & Bayerische Hypo-und Vereinsbank AG & $\mathrm{DE}$ & 25 & $\mathrm{~s}$ & & & $\mathrm{~s}$ & & & $\mathrm{~S}(2)$ & S (2) & & & $\mathrm{s}$ & $\mathrm{s}$ & $\mathrm{B}$ & & & $\mathrm{S}(3)$ & $\mathrm{s}$ & $\mathrm{s}$ & & \\
\hline 21 & Morgan Stanley & US & 24 & & & $\mathrm{~s}$ & & & & & & & & & & & & & & & & & \\
\hline 22 & Societe Generale & FR & 46 & $\mathrm{~s}$ & & $\mathrm{~S}$ & $\mathrm{~s}$ & & & & $\mathrm{~S}$ & & & & & & & & $\mathrm{~B}$ & $\mathrm{~s}$ & $\mathrm{~s}$ & $\mathrm{~B}$ & \\
\hline 23 & Norinchukin Bank (The) & $\mathrm{JP}$ & 3 & & & & & & & & & & & & & & & & & & & & \\
\hline 24 & Fortis & $\mathrm{BE}$ & 22 & & & & & & & & & & & & & & & & $\mathrm{~S}$ & & & & . \\
\hline 25 & Merrill Lynch \& Co., Inc. & US & 9 & & & $\mathrm{~s}$ & & & & & & & & & & & & & $\mathrm{~S}$ & & & & $\mathrm{~S}$ \\
\hline 26 & Commerzbank AG & $\mathrm{DE}$ & 22 & & & & & & & & $\mathrm{~B}$ & & & $\mathrm{~S}$ & & & & & $\mathrm{~S}(2)$ & & & & \\
\hline 27 & General Electric Capital Corp. & US & 13 & $\mathrm{~s}$ & & $\mathrm{~s}$ & & & & & $\mathrm{~S}$ & & & $\mathrm{~S}$ & & & $\mathrm{~s}$ & & $\mathrm{~s}$ & & & & \\
\hline 28 & Bank of CN & $\mathrm{CN}$ & 20 & & & & & & & & & & & & & & & & & & & & \\
\hline 29 & Dresdner Bank AG & $\mathrm{DE}$ & 26 & & & $\mathrm{~B}, \mathrm{~S}$ & & $\mathrm{~s}$ & & $\mathrm{~s}$ & $\mathrm{~s}$ & & & & & & $\mathrm{~S}$ & & $S$ & & & & \\
\hline 30 & Rabobank Group & $\mathrm{NL}$ & 19 & & & $\mathrm{~S}$ & & & & & & & & & & & & & $\mathrm{~S}$ & & & & \\
\hline 31 & China Construction Bank & $\mathrm{CN}$ & 4 & & & & & & & & & & & & & & & & & & & & \\
\hline 32 & Dexia & $\mathrm{BE}$ & 13 & & & & & & & & & & & & & & & & & $\mathrm{~s}$ & & & \\
\hline 33 & Agricultural Bank of China & $\mathrm{CN}$ & 2 & & & & & & & & & & & & & & & & & & & & \\
\hline 34 & NRW.BANK (WestLB) & $\mathrm{DE}$ & 18 & & & $\mathrm{~S}$ & & & & & & & & $\mathrm{~S}$ & & & & & $\mathrm{~S}$ & & & $\mathrm{~B}$ & \\
\hline 35 & Goldman Sachs Group, Inc & US & 6 & & & $\mathrm{~S}$ & & & & & & & & & & & & & & & & & \\
\hline 36 & Wells Fargo \& Company & US & 8 & & & & & & & & & & & & & & & & & & & & \\
\hline 37 & DZ Bank AG & $\mathrm{DE}$ & 13 & & & & & & & & & & & $\mathrm{~s}$ & & & & & $\mathrm{~s}$ & & & & \\
\hline 38 & Wachovia Corporation & US & 5 & & & & & & & & & & & & & & & & & & & & \\
\hline 39 & Resona Holdings, Inc & $\mathrm{JP}$ & 6 & & & & & & & & & & & & & & & & & & & & \\
\hline 40 & Bayerische Landesbank & $\mathrm{DE}$ & 5 & & & & & & & $\mathrm{~s}$ & & & & $\mathrm{~s}$ & & & & & & & & & \\
\hline 41 & Lloyds TSB Bank Plc & $\mathrm{UK}$ & 23 & $\mathrm{~B}$ & & $\mathrm{~B}, \mathrm{~S}$ & & & $\mathrm{~s}$ & & & $\mathrm{~B}$ & & & & & & & & & & & $\mathrm{~B}$ \\
\hline 42 & Santander Central Hispano Group & ES & 24 & $\mathrm{~s}$ & $\mathrm{~s}$ & S (4) & & $\mathrm{s}$ & $\mathrm{S}$ & & & & & & & & $\mathrm{S}(2)$ & $\mathrm{S}$ & & & & & $\mathrm{S}$ \\
\hline 43 & Landesbank Baden-Wuerttemberg & $\mathrm{DE}$ & 6 & & & & & & & & & & & & & & & & & & & & \\
\hline 44 & KfW Group & $\mathrm{DE}$ & 0 & & & & & & & & & & & & & & & & & & & & \\
\hline 45 & Prudential Financial Inc & US & 1 & & & & & & & & & & & & & & & & & & & & \\
\hline 46 & Banca Intesa SpA & IT & 19 & & & S (3) & & B & $\mathrm{S}$ & S (4) & $\mathrm{S}^{\text {(a) }}$ & & & $\mathrm{s}$ & & & & $\mathrm{S}$ & & $\mathrm{S}(2)$ & & & $\mathrm{B}$ \\
\hline 47 & Banco Bilbao Vizcaya Argentaria & ES & 21 & $\mathrm{~s}$ & & $S(3)$ & & $\mathrm{S}$ & $\mathrm{S}$ & & & & & & & & $\mathrm{S}(2)$ & $\mathrm{S}$ & & & & & $\mathrm{S}$ \\
\hline 48 & Abbey National Plc & $\mathrm{UK}$ & 1 & & & & & & & & & & & & & & & & & & & & \\
\hline 49 & Bank One Corporation & US & 8 & & & & & & & & & & & & & & $\mathrm{~B}$ & & & & & & \\
\hline 50 & Washington Mutual Inc. & US & 0 & & & & & & & & & & & & & & & & & & & & \\
\hline
\end{tabular}

This table contains information about the top 100 international commercial banks, classified by assets as of 2002. B stands for Branch. S stands for Subsidiary; S(\#) indicates the number of subsidiaries in the country. Countries codes used: $\mathrm{AT}$ = Austria; $\mathrm{AU}$ = Australia; $\mathrm{BE}=$ Belgium; $\mathrm{CA}$ = Canada; $\mathrm{CH}=$ Switzerland; $\mathrm{CN}$ = China; DE = Germany; $\mathrm{DK}=$ Denmark; ES = Spain; FR = France; HK = Hong Kong; IE = Ireland; IT = Italy; KP = Korea; JP = Japan; NL = Netherlands; SE = Sweden; UK = United Kingdom; US =USA. ${ }^{(a)}$ One branch operating in the country was coded as a subsidiary because it was a branch of a subsidiary of one of the top 100 banks operating in a developing country. 
Table 1 - Top 100 International Commercial Banks and Their Operations in Eastern Europe and Latin America, 2002 (continued)

\begin{tabular}{|c|c|c|c|c|c|c|c|c|c|c|c|c|c|c|c|c|c|c|c|c|c|c|c|}
\hline 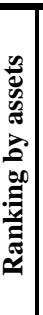 & Parent bank names & 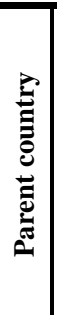 & 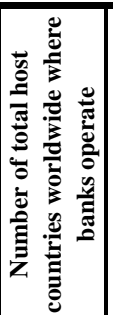 & 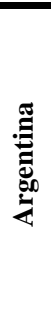 & فำ & 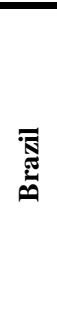 & 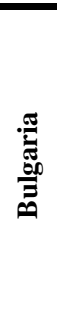 & 坣 & 音 & 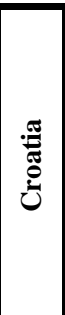 & 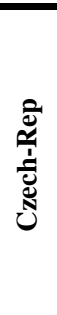 & 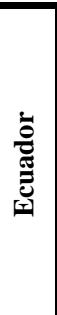 & 营 & 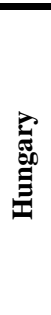 & 丞 & 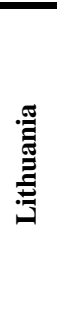 & $\frac{\stackrel{8}{x}}{\sum}$ & تِّلِ & $\begin{array}{l}\text { 츙 } \\
\text { : }\end{array}$ & $\begin{array}{l}\frac{\pi}{x} \\
\frac{\pi}{\pi} \\
\frac{0}{\omega}\end{array}$ & 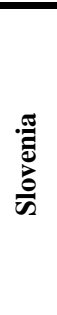 & 胥 & 胥 \\
\hline 51 & Almanij & $\mathrm{BE}$ & \begin{tabular}{|l|}
24 \\
\end{tabular} & $\mathrm{~B}$ & & & & & & & $\mathrm{~S}(2)$ & & & $\mathrm{s}$ & & & & & $\mathrm{s}$ & $S(2)^{(a)}$ & & & \\
\hline 52 & Credit Mutuel Centre Est Europe & FR & 10 & & & & & & & & & & & & & & & & & & & & \\
\hline 53 & CDC Ixis & FR & 0 & & & & & & & & & & & & & & & & & & & & \\
\hline 54 & Nordea Bank AB & $\mathrm{SE}$ & 14 & & & & & & & & & & $\mathrm{~B}$ & & $\mathrm{~B}$ & $\mathrm{~B}$ & & & $\mathrm{~s}$ & & & & \\
\hline 55 & Lehman Brothers Holdings Inc. & US & 16 & & & & & & & & & & & & & & & & & & & & \\
\hline 56 & Danske Bank A/S & $\mathrm{DK}$ & 8 & & & & & & & & & & & & & & & & $\mathrm{~s}$ & & & & \\
\hline 57 & Eurohypo AG & $\mathrm{DE}$ & 8 & & & & & & & & & & & & & & & & & & & & \\
\hline 58 & Royal Bank of CA RBC & $\mathrm{CA}$ & 10 & & & & & & & & & & & & & & & & & & & & \\
\hline 59 & UniCredito Italiano SpA & IT & 19 & & & & $\mathrm{~S}$ & & & S (3) & $\mathrm{S}$ & & & & & & & & $\mathrm{S}$ & $\mathrm{s}$ & & $\mathrm{S}$ & \\
\hline 60 & Shinkin Central Bank & JP & 2 & & & & & & & & & & & & & & & & & & & & \\
\hline 61 & San Paolo IMI & IT & 18 & & & & & & & & & & & $\mathrm{~S}$ & & - & & & & & $\mathrm{S}$ & & \\
\hline 62 & HSH Nordbank AG - Proforma & $\mathrm{DE}$ & 8 & & & & & & & & & & & & & & & & & & & & \\
\hline 63 & National AU Bank & $\mathrm{AU}$ & 9 & & & & & & & & & & & & & & & & & & & & \\
\hline 64 & NORD/LB & $\mathrm{DE}$ & 11 & & & & & & & & & & & & $\mathrm{~S}$ & $\mathrm{~S}$ & & & $\mathrm{~s}$ & & & & \\
\hline 65 & Fleet National Bank & US & 12 & B & & $\mathrm{B}, \mathrm{S}$ & & B & $\mathrm{s}$ & & & & & & & & B & B & & & & & $\mathrm{B}, \mathrm{S}$ \\
\hline 66 & Bear Stearns Companies Inc. & US & 4 & & & & & & & & & & & & & & & & & & & & \\
\hline 67 & Bank of Nova Scotia (The) & $\mathrm{CA}$ & 30 & & & & & $\mathrm{~s}$ & & & & & & & & & $\mathrm{~s}$ & & & & & & \\
\hline 68 & Bankgesellschaft Berlin AG & $\mathrm{DE}$ & 5 & & & & & & & & & & & & & & & & $\mathrm{~s}$ & & & & \\
\hline 69 & US Bancorp & US & 0 & & & & & & & & & & & & & & & & & & & & \\
\hline 70 & Nomura Holdings Inc & JP & 7 & & & & & & & & & & & & & & & & & & & & \\
\hline 71 & Toronto Dominion Bank & $\mathrm{CA}$ & 7 & & & & & & & & & & & & & & & & & & & & \\
\hline 72 & Canadian Imperial Bank of Com. & $\mathrm{CA}$ & 12 & & & & & & & & & & & & & & & & & & & & \\
\hline 73 & Banque de Montreal & $\mathrm{CA}$ & 6 & & & & & & & & & & & & & & & & & & & & \\
\hline 74 & Kookmin Bank & KP & 5 & & & & & & & & & & & & & & & & & & & & \\
\hline 75 & American Express Company & US & 28 & $\mathrm{~s}$ & & $\mathrm{~S}(2)$ & & & & & & & & & & & $\mathrm{B}$ & & & & & & $\mathrm{S}$ \\
\hline 76 & CNCEP & FR & 1 & & & & & & & & & & & & & & & & & & & & \\
\hline 77 & Landesbank Hessen- HELABA & $\mathrm{DE}$ & 4 & & & & & & & & & & & & & & & & & & & & \\
\hline 78 & Deutsche Postbank AG & $\mathrm{DE}$ & 2 & & & & & & & & & & & & & & & & & & & & \\
\hline 79 & Depfa Bank Plc & IE & 5 & & & & & & & & & & & & & & & & & & & & \\
\hline 80 & Capitalia SpA & IT & 12 & & & & & & & & & & & & & & & & & & & $\mathrm{~B}$ & \\
\hline 81 & Sumitomo Trust \& Banking Co & JP & 5 & & & & & & & & & & & & & & & & & & & & \\
\hline 82 & National Agricultural Coop. Fed. & $\mathrm{KP}$ & 0 & & & & & & & & & & & & & & & & & & & & \\
\hline 83 & Svenska Handelsbanken & SE & 2 & & & & & & & & & & & & & & & & $\mathrm{~S}$ & & & & \\
\hline 84 & Natexis Banques Populaires & FR & 12 & & & & & & & & & & & & & & & & & & & & \\
\hline 85 & Banca Monte dei Paschi di Siena & IT & 9 & & & & & & & & & & & & & & & & & & & & \\
\hline 86 & Skandinaviska Enskilda Banken & $\mathrm{SE}$ & 12 & & & & & & & & & & $\mathrm{~s}$ & & $\mathrm{~S}$ & $\mathrm{~S}$ & & & & & & & \\
\hline 87 & Commonwealth Bank of AU & $\mathrm{AU}$ & 9 & & & & & & & & & & & & & & & & & & & & \\
\hline 88 & Erste Bank der Oesterreichischen S. & $\mathrm{AT}$ & 8 & & & & & & & $\mathrm{~S}(2)$ & $S(2)$ & & & $\mathrm{S}$ & & & & & & $\mathrm{s}$ & & & \\
\hline 89 & Chuo Mitsui Trust \& Banking Co & JP & 0 & & & & & & & & & & & & & & & & & & & & \\
\hline 90 & National City Corporation & US & 2 & & & & & & & & & & & & & & & & & & & & \\
\hline 91 & SunTrust Banks, Inc. & US & 1 & & & & & & & & & & & & & & & & & & & & \\
\hline 92 & BHW Holdings AG & $\mathrm{DE}$ & 0 & & & & & & & & & & & & & & & & & & & & \\
\hline 93 & Standard Chartered Plc & UK & 43 & & & & & & $\mathrm{~s}$ & & & & & & & & & $\mathrm{~B}$ & & & & & \\
\hline 94 & LA CAIXA (Barcelona) & ES & 2 & & & & & & & & & & & & & & & & & & & & \\
\hline 95 & Shoko Chukin Bank, Ltd & JP & 0 & & & & & & & & & & & & & & & & & & & & \\
\hline 96 & Foereningssparbanken & $\mathrm{SE}$ & 8 & & & & & & & & & & $\mathrm{~s}$ & & $\mathrm{~s}$ & $\mathrm{~s}$ & & & & & & & \\
\hline 97 & State Bank of India & IN & 14 & & & & & & & & & & & & & & & & & & & & \\
\hline 98 & Westpac Banking Corporation & $\mathrm{AU}$ & 11 & & & & & & & & & & & & & & & & & & & & \\
\hline 99 & Woori Financial Holdings Co. Ltd & KP & 10 & & & & & & & & & & & & & & & & & & & & \\
\hline 100 & Bank of China (HK) Limited & $\mathrm{HK}$ & 2 & & & & & & & & & & & & & & & & & & & & \\
\hline
\end{tabular}

This table contains information about the top 100 international commercial banks, classified by assets as of 2002. B stands for Branch. S stands for Subsidiary; $\mathrm{S}(\#)$ indicates the number of subsidiaries in the country. Countries codes used: $\mathrm{AT}$ = Austria; $\mathrm{AU}=$ Australia; $\mathrm{BE}=$ Belgium; $\mathrm{CA}$ = Canada; $\mathrm{CH}=$ Switzerland; $\mathrm{CN}$ = China; DE = Germany; DK = Denmark; ES = Spain; FR = France; HK = Hong Kong; IE = Ireland; IT = Italy; KP = Korea; JP = Japan; NL = Netherlands; SE = Sweden; UK = United Kingdom; US =USA. ${ }^{(a)}$ One branch operating in the country was coded as a subsidiary because it was a branch of a subsidiary of one of the top 100 banks operating in a developing country.

Sources: Bankscope, National Central Banks, and Bankers Almanac. 
Table 2: Foreign Bank Presence in Eastern Europe and Latin America

\begin{tabular}{|c|c|c|c|c|c|c|c|}
\hline Countries & $\begin{array}{c}\text { Number of } \\
\text { Banks }\end{array}$ & $\begin{array}{c}\text { Number of Banks } \\
\text { under Foreign } \\
\text { Control }^{\text {a) }} \\
\end{array}$ & $\begin{array}{c}\text { Number of } \\
\text { Foreign } \\
\text { Subsidiaries } \\
\end{array}$ & $\begin{array}{c}\text { Number of } \\
\text { Foreign } \\
\text { Branches } \\
\end{array}$ & $\begin{array}{c}\text { Number of } \\
\text { Top } 100 \\
\text { Subsidiaries }^{\text {b) }} \\
\end{array}$ & $\begin{array}{c}\text { Number of } \\
\text { Top } 100 \\
\text { Branches }^{\text {c) }}\end{array}$ & $\begin{array}{c}\text { Top } 100 \text { Foreign Banks' } \\
\text { Asset Share Within Foreign } \\
\text { Controlled Banks }{ }^{\text {d) }}\end{array}$ \\
\hline Argentina & 79 & 30 & 15 & 15 & 10 & 10 & $89.99 \%$ \\
\hline Bolivia & 12 & 5 & 2 & 3 & 1 & 1 & $58.79 \%$ \\
\hline Brazil & 193 & 73 & 64 & 9 & 38 & 6 & $91.14 \%$ \\
\hline Bulgaria & 34 & 21 & 15 & 6 & 4 & 2 & $40.61 \%$ \\
\hline Chile & 25 & 14 & 6 & 8 & 6 & 6 & $97.70 \%$ \\
\hline Croatia & 46 & 21 & 21 & 0 & 13 & 0 & $75.16 \%$ \\
\hline Czech Republic & 37 & 26 & 17 & 9 & 13 & 5 & $84.74 \%$ \\
\hline Ecuador & 22 & 2 & 0 & 2 & 0 & 2 & $100.00 \%$ \\
\hline Estonia & 7 & 4 & 3 & 1 & 2 & 1 & $92.30 \%$ \\
\hline Hungary & 39 & 25 & 25 & 0 & 15 & 0 & $60.56 \%$ \\
\hline Latvia & 23 & 9 & 8 & 1 & 4 & 1 & $87.55 \%$ \\
\hline Lithuania & 13 & 8 & 5 & 3 & 4 & 2 & $92.78 \%$ \\
\hline Mexico & 33 & 21 & 11 & 10 & 10 & 10 & $99.72 \%$ \\
\hline Peru & 15 & 12 & 9 & 3 & 4 & 3 & $52.43 \%$ \\
\hline Poland $^{\mathrm{e})}$ & 59 & 45 & 44 & 1 & 29 & 1 & $79.25 \%$ \\
\hline Slovak Republic & 20 & 17 & 15 & 2 & 11 & 1 & $75.16 \%$ \\
\hline Slovenia & 22 & 7 & 6 & 1 & 3 & 0 & $77.86 \%$ \\
\hline Turkey & 54 & 19 & 8 & 11 & 4 & 9 & $94.35 \%$ \\
\hline Uruguay & 41 & 28 & 18 & 10 & 11 & 5 & $77.17 \%$ \\
\hline TOTAL & 774 & 387 & 292 & 95 & 182 & 65 & - \\
\hline
\end{tabular}

Sources: National Central Banks, Bankers Almanac, Bankscope, and Others.

a) Foreign banks with at least $50 \%$ of the bank capital; b) Number of subsidiaries under foreign banks' control whose parent banks are within the top 100 worldwide banks, classified by assets at 2002; c) Number of foreign branches whose parent banks are within the top 100 worldwide banks, classified by assets at 2002 - 4 branches in the sample of Top 100 subsidiaries incorporated in a developing country were classified as subsidiaries; d) Figures for Czech Republic, Estonia, Latvia, Poland, Slovak Republic and Uruguay underestimate the representativeness of the foreign banks in the sample due to missing asset data. Bulgaria's low foreign asset share is due to the important participation of banks from Greece and Hungary which are not classified within the top 100 banks. Peru's low foreign asset share data is due to the importance of Banco de Credito del Peru and Interbank's shareholders which are companies from Bermuda and Bahamas respectively. Finally, Bolivia's low asset share is due to the importance of Banco de Credito de Bolivia whose main shareholder is Banco de Credito del Peru; and e) It does not include 605 cooperatives banks (They represent $6.5 \%$ of total assets) 
Table 3 - Top 100 Parent Bank Activities by Country of Origin (Home) and Home Country Regulations on Overseas Activities

\begin{tabular}{|c|c|c|c|c|c|c|c|}
\hline Countries & $\begin{array}{c}\text { Number of Top } 100 \\
\text { Banks by Assets in } \\
2002\end{array}$ & $\begin{array}{c}\text { Assets' Share Among } \\
\text { Top } 100 \text { Banks }\end{array}$ & $\begin{array}{c}\text { Number of Top } 100 \\
\text { Banks with Operations } \\
\text { in Sample of Host } \\
\text { Countries }\end{array}$ & $\begin{array}{l}\text { Number of Host } \\
\text { Countries where } \\
\text { Banks Operate }\end{array}$ & $\begin{array}{c}\text { Number of } \\
\text { Subsidiaries in } \\
\text { Sample of Host } \\
\text { Countries } \\
\end{array}$ & $\begin{array}{c}\text { Number of Branches } \\
\text { in Sample of Host } \\
\text { Countries }\end{array}$ & $\begin{array}{c}\text { Home Country } \\
\text { Branch/Sub } \\
\text { Regulation Dummy }\end{array}$ \\
\hline Australia & 3 & $1.26 \%$ & 0 & 0 & 0 & 0 & 0 \\
\hline Austria & 1 & $0.37 \%$ & 1 & 4 & 6 & 0 & 0 \\
\hline Belgium & 3 & $3.32 \%$ & 3 & 5 & 8 & 1 & 0 \\
\hline Canada & 5 & $2.70 \%$ & 1 & 2 & 2 & 0 & $1^{\text {(a) }}$ \\
\hline China & 4 & $5.10 \%$ & 0 & 0 & 0 & 0 & $0^{*}$ \\
\hline Denmark & 1 & $0.72 \%$ & 1 & 1 & 1 & 0 & 0 \\
\hline France & 7 & $7.90 \%$ & 3 & 11 & 22 & 4 & 0 \\
\hline Germany & 16 & $14.97 \%$ & 8 & 15 & 42 & 6 & $1^{(\mathrm{b})}$ \\
\hline Hong Kong & 1 & $0.28 \%$ & 0 & 0 & 0 & 0 & 0 \\
\hline India & 1 & $0.31 \%$ & 0 & 0 & 0 & 0 & $1^{(\mathrm{c})}$ \\
\hline Ireland & 1 & $0.45 \%$ & 0 & 0 & 0 & 0 & 0 \\
\hline Italy & 5 & $2.94 \%$ & 4 & 14 & 23 & 3 & $1^{(\mathrm{d})}$ \\
\hline Japan & 11 & $14.55 \%$ & 2 & 5 & 3 & 3 & 0 \\
\hline Korea & 3 & $1.16 \%$ & 0 & 0 & 0 & 0 & 0 \\
\hline Netherlands & 3 & $5.06 \%$ & 3 & 12 & 8 & 12 & 0 \\
\hline Spain & 3 & $2.14 \%$ & 2 & 8 & 20 & 0 & $1^{(\mathrm{e})}$ \\
\hline Sweden & 4 & $1.88 \%$ & 4 & 4 & 8 & 3 & 0 \\
\hline Switzerland & 2 & $4.50 \%$ & 2 & 3 & 3 & 2 & 0 \\
\hline United Kingdom & 6 & $9.81 \%$ & 4 & 11 & 10 & 7 & 0 \\
\hline United States & 20 & $20.57 \%$ & 10 & 15 & 26 & 24 & 0 \\
\hline Total & 100 & $100.00 \%$ & 48 & 20 & 182 & 65 & - \\
\hline
\end{tabular}

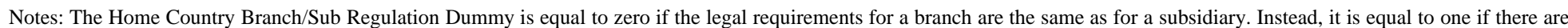

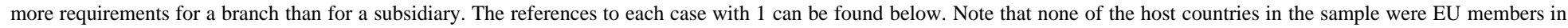
2002.

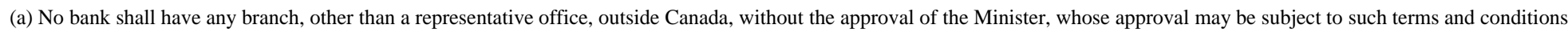
as the Minister considers appropriate (Banking Act, art 422).

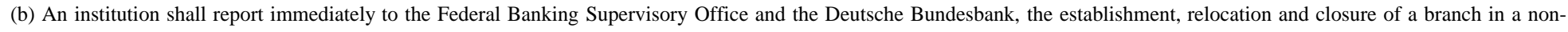
EEA state (Banking Act, art 24 (7)).

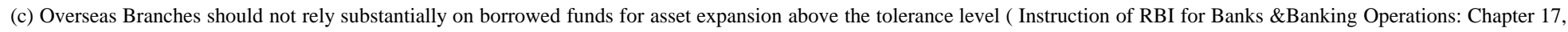

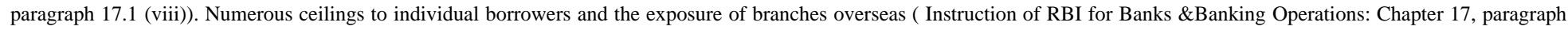

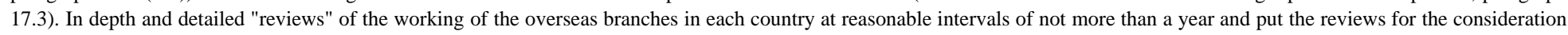
of the Top management and the Board of Directors ( Instruction of RBI for Banks \&Banking Operations: Chapter 17, paragraph 17.11 (v)).

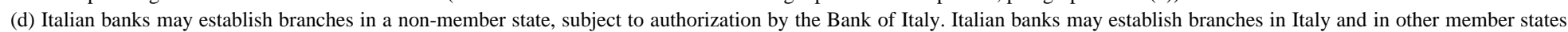
(Banking Act, art 15(2)).

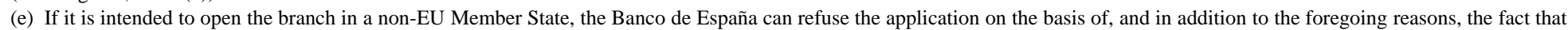

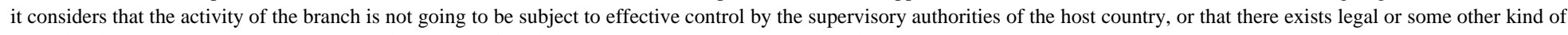
obstacles that prevent or hamper control and inspection of the branch by the Banco de España . (Real Decreto 1245/1995, art 13)

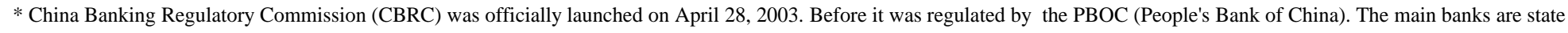
banks. No legislation was found for that period.

Source: Parent Countries' Banking Sector Regulations, National Central Banks, Bankers Almanac, and Bankscope. 
Table 4 - Host Country Regulation on the Organizational Choice of Foreign Banks: Branch vs. Subsidiary Index

\begin{tabular}{|c|c|c|c|c|c|}
\hline Countries & $\begin{array}{c}\text { Written } \\
\text { Statements }\end{array}$ & $\begin{array}{c}\text { Restriction on } \\
\text { Activities }\end{array}$ & $\begin{array}{c}\text { Responsibilities } \\
\text { Undertaken }\end{array}$ & Other Restrictions & $\begin{array}{c}\text { Host Country } \\
\text { Regulation Index }\end{array}$ \\
\hline Argentina & 0 & 0 & 0 & 0 & $\mathbf{0}$ \\
\hline Bolivia & $1^{\text {(a) }}$ & 0 & 0 & 0 & 1 \\
\hline Brazil & 0 & 0 & 0 & 0 & $\mathbf{0}$ \\
\hline Bulgaria & $1^{\text {(b) }}$ & 0 & 0 & 0 & 1 \\
\hline Chile & 0 & 0 & 0 & 0 & $\mathbf{0}$ \\
\hline Croatia & $1^{\text {(c) }}$ & $1^{\text {(d) }}$ & $1^{(\mathrm{e})}$ & 0 & 3 \\
\hline Czech Republic & 0 & 0 & 0 & 0 & $\mathbf{0}$ \\
\hline Ecuador & 0 & 0 & 0 & 0 & $\mathbf{0}$ \\
\hline Estonia & 0 & 0 & 0 & 0 & $\mathbf{0}$ \\
\hline Hungary & 0 & $1^{(\mathrm{f})}$ & 0 & $1^{(\mathrm{g})}$ & 2 \\
\hline Latvia & 0 & 0 & 0 & 0 & $\mathbf{0}$ \\
\hline Lithuania & 0 & 0 & 0 & 0 & $\mathbf{0}$ \\
\hline Mexico & 0 & $1^{\text {(h) }}$ & 0 & 0 & 1 \\
\hline Peru & 0 & 0 & 0 & 0 & $\mathbf{0}$ \\
\hline Poland & 0 & 0 & $1^{(1)}$ & $1^{(\mathrm{J})}$ & 2 \\
\hline Slovak Republic & 0 & $1^{(\mathrm{k})}$ & 0 & 0 & 1 \\
\hline Slovenia & 0 & 0 & 0 & 0 & $\mathbf{0}$ \\
\hline Turkey & 0 & 0 & 0 & 0 & $\mathbf{0}$ \\
\hline Uruguay & 0 & 0 & 0 & 0 & $\mathbf{0}$ \\
\hline
\end{tabular}

Notes: This table explains how the Host Country Regulation Index was constructed. The index was developed using four subcategories: Required Written Statements, Restrictions on Activities, Responsibilities Undertaken and Other Restrictions. Each category is equal to zero if the legal requirements for a branch are the same as for a subsidiary. They are equal to one if there are more requirements for a branch than for a subsidiary. An explanation when each subcomponent equals 1 can be found below. Source: Host Countries' Banking Sector Regulations

(a) Written approval of bank supervisory body of country of domicile required to open a bank branch (Law of Financial Institutions, art 17 (1))

(b) Written approval of bank supervisory body of country of domicile required for opening a bank branch (Law of Banks, art 12). Also written statement of the bank's supervisory body agreeing exchange of information and prompt notification of news to the Bulgarian authorities (Regulation 2, section II).

(c) (Among others) An opinion or approval of the supervisory authority of a bank of a Member State or the supervisory authority of a foreign bank on a bank that intends to establish a bank in the Republic of Croatia. (Banking Law, art 35)

(d) A branch office of Foreign banks shall not perform the activities determined by the provisions of Articles 35, 36 and 37 of the Banking Act (e.g. receive deposits, etc). Special conditions for operating a branch office of foreign banks shall be regulated by Croatia National Bank (Banking Act, art 21)

(e) A branch may conduct operations within the Republic of Croatia pursuant to the authorization of the founder bank and with the implicit responsibility of the founder bank for all obligations undertaken in the Republic of Croatia in relation to the operations of the branch. (Banking Law, art 51)

(f) Unless otherwise provided for by an international agreement, the Government may, based on a law or an authorization granted by law, prescribe by decree that only economic organizations with business offices registered in Hungary or organizations under full or majority ownership of domestic residents may be entitled to perform certain activities. (Branch Act, section 8)

(g) A branch office may be entered in the company registration records if an international agreement concluded with the country, or international organization, where the registered office, in which the foreign company is located, allows the foreign company to establish a branch office in Hungary. (Branch Act, section 5) From 1 January 1998, The Branch Act recognizes and authorizes for the first time the "branch" as a legal form of establishment in Hungary.

(h) The Secretariat of Finance and Public Credit may authorize the establishment in the Republic of branches of pre-eminent foreign banks, whose borrowing and lending operations may be conducted only with residents outside Mexico. (Law of Credit Institutions, art 7)

(i) The application shall have appended thereto an undertaking from the applicant foreign bank that it will satisfy all claims on the branch that may arise from its relations with other organizations. (Banking act, art40 (3))

(j) The Commission for Banking Supervision stated in a debate that the most appropriate form of foreign organization in the baking business in Poland would be a joint-stock bank (source: The Polish Banking System in the Nineties, National Bank of Poland, December 2001) The authorization of the Commission for Banking Supervision is a requirement for the establishment of a branch of a foreign bank (Banking Act, art 40)

(k) A branch of a foreign bank may only be permitted mortgage transactions if the foreign bank applying for the license has a license to perform mortgage transactions in the home country.(Banking Act, art 8(9)) 
Table 5: Probit Estimation of the Likelihood that a Foreign Bank Operates as a Branch

\begin{tabular}{|c|c|c|c|c|c|c|}
\hline \multirow[t]{2}{*}{ Independent Variables } & \multicolumn{6}{|c|}{ Dependent variable: Branch=1 ; Subsidiary=0 } \\
\hline & Model (1) & Model (2) & Model (3) & Model (4) & Model (5) & Model (6) \\
\hline $\begin{array}{l}\text { Parent Bank } \\
\text { Internationalization Strategy }\end{array}$ & $\begin{array}{c}3.2184 \\
(1.2427) * * *\end{array}$ & $\begin{array}{c}3.2301 \\
(1.2898) * *\end{array}$ & \begin{tabular}{|c|}
3.2417 \\
$(1.2018) * * *$
\end{tabular} & $\begin{array}{c}3.2423 \\
(1.2685) * *\end{array}$ & $\begin{array}{c}3.3866 \\
(1.3389) * *\end{array}$ & $\begin{array}{c}3.3889 \\
(1.3096) * * *\end{array}$ \\
\hline Parent Bank Size & $\begin{array}{r}-0.3850 \\
(0.2384) \\
\end{array}$ & $\begin{array}{c}-0.4297 \\
(0.2439) * \\
\end{array}$ & \begin{tabular}{|c|}
-0.2856 \\
$(0.2348)$ \\
\end{tabular} & $\begin{array}{r}-0.3066 \\
(0.2612) \\
\end{array}$ & $\begin{array}{r}-0.3982 \\
(0.2506) \\
\end{array}$ & $\begin{array}{r}-0.3055 \\
(0.3026) \\
\end{array}$ \\
\hline $\begin{array}{l}\text { Parent Bank } \\
\text { Business Orientation } \\
\end{array}$ & $\begin{array}{r}0.7049 \\
(0.5195) \\
\end{array}$ & $\begin{array}{r}0.7855 \\
(0.5177) \\
\end{array}$ & $\begin{array}{r}0.4869 \\
(0.5257) \\
\end{array}$ & $\begin{array}{r}0.4520 \\
(0.5494) \\
\end{array}$ & $\begin{array}{r}0.6776 \\
(0.5222) \\
\end{array}$ & $\begin{array}{r}0.4740 \\
(0.5361) \\
\end{array}$ \\
\hline $\begin{array}{l}\text { Home Country Regulations } \\
\text { on Overseas Branches }\end{array}$ & $\begin{array}{c}-0.7429 \\
(0.3003) * *\end{array}$ & $\begin{array}{c}-0.7475 \\
(0.2927) * *\end{array}$ & \begin{tabular}{|l}
-0.8104 \\
$(0.2972) * * *$
\end{tabular} & $\begin{array}{c}-0.8473 \\
(0.2990) * * *\end{array}$ & $\begin{array}{c}-0.7094 \\
(0.2921) * * \\
\end{array}$ & $\begin{array}{c}-0.7671 \\
(0.3026) * * \\
\end{array}$ \\
\hline Affiliate Bank Size & $\begin{array}{c}-0.2540 \\
(0.1495) * \\
\end{array}$ & $\begin{array}{r}-0.2675 \\
(0.1650) \\
\end{array}$ & $\begin{array}{c}-0.2772 \\
(0.1457) * \\
\end{array}$ & $\begin{array}{c}-0.3061 \\
(0.1677) * \\
\end{array}$ & $\begin{array}{c}-0.2954 \\
(0.1628) * \\
\end{array}$ & $\begin{array}{c}-0.3127 \\
(0.1588) * *\end{array}$ \\
\hline $\begin{array}{l}\text { Affiliate Bank } \\
\text { Business Orientation }\end{array}$ & $\begin{array}{c}-0.8470 \\
(0.3493)^{* *}\end{array}$ & $\begin{array}{c}-0.8757 \\
(0.3406) * * *\end{array}$ & \begin{tabular}{|c|}
-0.8758 \\
$(0.3398) * * *$
\end{tabular} & $\begin{array}{c}-0.9615 \\
(0.3197) * * *\end{array}$ & $\begin{array}{c}-0.8226 \\
(0.3290) * *\end{array}$ & $\begin{array}{c}-0.8351 \\
(0.3246) * * *\end{array}$ \\
\hline Year of Entry & $\begin{array}{c}-0.0314 \\
(0.0059) * * *\end{array}$ & $\begin{array}{c}-0.0307 \\
(0.0054) * * *\end{array}$ & \begin{tabular}{|c|}
-0.0346 \\
$(0.0060) * * *$
\end{tabular} & $\begin{array}{c}-0.0350 \\
(0.0054) * * *\end{array}$ & $\begin{array}{c}-0.0313 \\
(0.0052) * * *\end{array}$ & $\begin{array}{c}-0.0339 \\
(0.0055) * * * \\
\end{array}$ \\
\hline Acquisition Dummy & \begin{tabular}{|c|}
-1.5348 \\
$(0.3176) * * *$ \\
\end{tabular} & $\begin{array}{c}-1.5202 \\
(0.3585) * * * \\
\end{array}$ & \begin{tabular}{|l}
-1.8709 \\
$(0.4207) * * *$
\end{tabular} & $\begin{array}{c}-1.9289 \\
(0.4641) * * * \\
\end{array}$ & \begin{tabular}{|c|}
-1.7893 \\
$(0.4598) * * *$
\end{tabular} & $\begin{array}{l}-2.1227 \\
(0.5837) * * * \\
\end{array}$ \\
\hline $\begin{array}{l}\text { Host Country Regulations } \\
\text { on Foreign Bank Branches }\end{array}$ & $\begin{array}{c}-0.8380 \\
(0.3156) * * *\end{array}$ & $\begin{array}{c}-0.4418 \\
(0.2454) *\end{array}$ & $\begin{array}{c}-1.3679 \\
(0.3315) * * *\end{array}$ & $\begin{array}{c}-0.7232 \\
(0.2919) * *\end{array}$ & $\begin{array}{c}-0.6198 \\
(0.1999) * * *\end{array}$ & $\begin{array}{c}-1.1366 \\
(0.4189) * * *\end{array}$ \\
\hline $\begin{array}{l}\text { Host Country Bank } \\
\text { Entry Requirements }\end{array}$ & $\begin{array}{r}-0.2775 \\
(0.1863)\end{array}$ & $\begin{array}{r}-0.2230 \\
(0.1859)\end{array}$ & $\begin{array}{c}-0.4009 \\
(0.1940) * *\end{array}$ & $\begin{array}{r}-0.3381 \\
(0.2084)\end{array}$ & $\begin{array}{c}-0.3566 \\
(0.2142) * \\
\end{array}$ & $\begin{array}{c}-0.4776 \\
(0.2187) * * \\
\end{array}$ \\
\hline $\begin{array}{l}\text { Host Country Restrictions } \\
\text { on Bank Activities }\end{array}$ & $\begin{array}{r}0.1186 \\
(0.1153)\end{array}$ & $\begin{array}{c}0.1986 \\
(0.1163) *\end{array}$ & $\begin{array}{r}0.0121 \\
(0.1017)\end{array}$ & $\begin{array}{r}0.1336 \\
(0.1246)\end{array}$ & $\begin{array}{r}0.1659 \\
(0.1187) \\
\end{array}$ & $\begin{array}{r}0.0525 \\
(0.1306)\end{array}$ \\
\hline $\begin{array}{l}\text { Host Country } \\
\text { Corporate Taxes } \\
\end{array}$ & $\begin{array}{c}0.0703 \\
(0.0242) * * * \\
\end{array}$ & $\begin{array}{c}0.0581 \\
(0.0199) * * * \\
\end{array}$ & $\begin{array}{c}0.1020 \\
(0.0309) * * * \\
\end{array}$ & $\begin{array}{c}0.0894 \\
(0.0245) * * * \\
\end{array}$ & $\begin{array}{c}0.0899 \\
(0.0265) * * * \\
\end{array}$ & $\begin{array}{c}0.1191 \\
(0.0325) * * * \\
\end{array}$ \\
\hline Host Country Size & $\begin{array}{r}-0.0294 \\
(0.1363) \\
\end{array}$ & $\begin{array}{r}-0.1465 \\
(0.1276) \\
\end{array}$ & $\begin{array}{r}0.0924 \\
(0.0974) \\
\end{array}$ & $\begin{array}{r}-0.0909 \\
(0.1007)\end{array}$ & $\begin{array}{r}-0.1640 \\
(0.1130)\end{array}$ & $\begin{array}{r}-0.0317 \\
(0.1159)\end{array}$ \\
\hline $\begin{array}{l}\text { Host Country GDP } \\
\text { per Capita }\end{array}$ & \begin{tabular}{|c|}
-0.4807 \\
$(0.1308) * * *$
\end{tabular} & $\begin{array}{c}-0.3864 \\
(0.1328) * * *\end{array}$ & $\begin{array}{c}-0.5343 \\
(0.1354) * * *\end{array}$ & $\begin{array}{c}-0.3008 \\
(0.1341)^{* *}\end{array}$ & $\begin{array}{c}-0.5905 \\
(0.1259) * * *\end{array}$ & $\begin{array}{c}-0.6198 \\
(0.1385) * * *\end{array}$ \\
\hline $\begin{array}{l}\text { Host Country Risk } \\
\text { (Composite index) }\end{array}$ & $\begin{array}{r}0.0017 \\
(0.0389) \\
\end{array}$ & & & & & \\
\hline $\begin{array}{l}\text { Host Country } \\
\text { Political Risk }\end{array}$ & & $\begin{array}{r}0.0521 \\
(0.0353) \\
\end{array}$ & & $\begin{array}{c}0.1229 \\
(0.0378) * * * \\
\end{array}$ & & \\
\hline $\begin{array}{l}\text { Host Country } \\
\text { Economic Risk }\end{array}$ & & & $\begin{array}{c}-0.1172 \\
(0.0556) * *\end{array}$ & $\begin{array}{c}-0.2188 \\
(0.0668) * * *\end{array}$ & & $\begin{array}{c}-0.1134 \\
(0.0638) *\end{array}$ \\
\hline $\begin{array}{l}\text { Host Country } \\
\text { Investment Risk }\end{array}$ & & & & & $\begin{array}{c}0.2721 \\
(0.1203) * *\end{array}$ & $\begin{array}{c}0.2503 \\
(0.1356) *\end{array}$ \\
\hline Latin America Dummy & $\begin{array}{r}0.119648 \\
(0.3585) \\
\end{array}$ & $\begin{array}{r}0.0498 \\
(0.3588) \\
\end{array}$ & $\begin{array}{r}-0.1245 \\
(0.3910) \\
\end{array}$ & $\begin{array}{r}-0.5797 \\
(0.4333) \\
\end{array}$ & $\begin{array}{r}0.2952 \\
(0.3978) \\
\end{array}$ & $\begin{array}{r}0.0216 \\
(0.4477) \\
\end{array}$ \\
\hline $\begin{array}{l}\text { Number of Observations } \\
\text { Pseudo R-squared } \\
\text { Wald chi2 } \\
\text { P-value of Wald chi2 }\end{array}$ & $\begin{array}{r}240 \\
0.576 \\
114.670 \\
0.000\end{array}$ & $\begin{array}{r}240 \\
0.5828 \\
116.900 \\
0.000\end{array}$ & $\begin{array}{r}240 \\
0.5884 \\
108.490 \\
0.000\end{array}$ & $\begin{array}{r}240 \\
0.6136 \\
194.960 \\
0.000\end{array}$ & $\begin{array}{r}240 \\
0.5865 \\
121.210 \\
0.000\end{array}$ & $\begin{array}{r}240 \\
0.5968 \\
126.480 \\
0.000\end{array}$ \\
\hline
\end{tabular}

This table reports probit regressions with standard error adjusted for clustering on each parent bank. A constant is estimated but not reported. Robust Standard Errors are in parentheses. *, **, *** mean significance at 10, 5 and 1 percent, respectively. 
Table 6: Impact of the Determinants of the Likelihood of a Foreign Bank Operating as a Branch

\begin{tabular}{|c|c|c|}
\hline Independent Variables & Marginal Effects & $\begin{array}{c}\text { Impact on the likelihood of operating } \\
\text { as a branch (in \% terms) }\end{array}$ \\
\hline $\begin{array}{l}\text { Parent Bank } \\
\text { Internationalization Strategy }\end{array}$ & 0.163 & 2.805 \\
\hline Parent Bank Size & -0.015 & -0.920 \\
\hline $\begin{array}{l}\text { Parent Bank } \\
\text { Business Orientation }\end{array}$ & 0.015 & 0.375 \\
\hline $\begin{array}{l}\text { Home Country Regulations } \\
\text { on Overseas Branches }\end{array}$ & -0.038 & -1.854 \\
\hline Affiliate Bank Size & -0.015 & -5.996 \\
\hline $\begin{array}{l}\text { Affiliate Bank } \\
\text { Business Orientation } \\
\end{array}$ & -0.063 & -3.124 \\
\hline Year of Entry & -0.002 & -4.368 \\
\hline Acquisition Dummy & -0.097 & -4.728 \\
\hline $\begin{array}{l}\text { Host Country Regulations } \\
\text { on Foreign Bank Branches }\end{array}$ & -0.036 & -3.453 \\
\hline $\begin{array}{l}\text { Host Country Bank } \\
\text { Entry Requirements } \\
\end{array}$ & -0.017 & -1.560 \\
\hline $\begin{array}{l}\text { Host Country Restrictions } \\
\text { on Bank Activities }\end{array}$ & 0.007 & 1.321 \\
\hline $\begin{array}{l}\text { Host Country } \\
\text { Corporate Taxes }\end{array}$ & 0.005 & 3.461 \\
\hline Host Country Size & -0.005 & -0.637 \\
\hline Host Country GDP per capita & -0.015 & -2.605 \\
\hline Host Country Political Risk & 0.006 & 4.319 \\
\hline Host Country Economic Risk & -0.011 & -3.174 \\
\hline Latin America Dummy & -0.030 & -1.505 \\
\hline
\end{tabular}

Note: The marginal effect of dummy variables is considered from a change from 0 to 1 
Table 7: $1^{\text {st }}$ Stage Heckman Probit Estimations of the Likelihood that a Foreign Bank Operates in a Host Country

\begin{tabular}{|c|c|c|c|c|c|c|c|c|c|c|c|c|}
\hline \multicolumn{13}{|c|}{ Dependent variable: Bank operates in the country $=1$; No operation in the host country $=0$} \\
\hline Independent Variables & Model (1 & & Model (2 & & Model (3 & & Model ( & & Model (5 & & Model ( & (6) \\
\hline Parent Bank Worldwide Activity & $\begin{array}{c}0.0361 \\
(0.0052)\end{array}$ & $* * *$ & $\begin{array}{c}0.0362 \\
(0.0053)\end{array}$ & $* * *$ & $\begin{array}{l}0.0361 \\
(0.0052)\end{array}$ & $* * *$ & $\begin{array}{c}0.0359 \\
(0.0052)\end{array}$ & $* * *$ & $\begin{array}{c}0.0361 \\
(0.0052) *\end{array}$ & $* * *$ & $\begin{array}{c}0.0360 \\
(0.0052)\end{array}$ & $* * *$ \\
\hline Parent Bank Size & $\begin{array}{c}0.1303 \\
(0.1506)\end{array}$ & & $\begin{array}{c}0.1277 \\
(0.1511)\end{array}$ & & $\begin{array}{c}0.1340 \\
(0.1503)\end{array}$ & & $\begin{array}{c}0.1400 \\
(0.1533)\end{array}$ & & $\begin{array}{c}0.1347 \\
(0.1513)\end{array}$ & & $\begin{array}{c}0.1362 \\
(0.1507)\end{array}$ & \\
\hline Parent Bank Business Orientation & $\begin{array}{c}0.1371 \\
(0.3389)\end{array}$ & & $\begin{array}{c}0.1330 \\
(0.3379)\end{array}$ & & $\begin{array}{c}0.1416 \\
(0.3393)\end{array}$ & & $\begin{array}{c}0.1465 \\
(0.3390)\end{array}$ & & $\begin{array}{c}0.1389 \\
(0.3395)\end{array}$ & & $\begin{array}{c}0.1421 \\
(0.3397)\end{array}$ & \\
\hline $\begin{array}{l}\text { Home Country (outward) } \\
\text { Foreign Investment Regulation }\end{array}$ & $\begin{array}{c}0.1774 \\
(0.3368)\end{array}$ & & $\begin{array}{c}0.1789 \\
(0.3401)\end{array}$ & & $\begin{array}{c}0.1805 \\
(0.3329)\end{array}$ & & $\begin{array}{c}0.1995 \\
(0.3364)\end{array}$ & & $\begin{array}{c}0.1856 \\
(0.3363)\end{array}$ & & $\begin{array}{c}0.1843 \\
(0.3320)\end{array}$ & \\
\hline $\begin{array}{l}\text { Host Country (inward) } \\
\text { Foreign Investment Regulation }\end{array}$ & $\begin{array}{l}-0.3093 \\
(0.0787)\end{array}$ & $* * *$ & $\begin{array}{l}-0.2725 \\
(0.0783)\end{array}$ & $* * *$ & $\begin{array}{l}-0.3298 \\
(0.0806)\end{array}$ & $* * *$ & $\begin{array}{l}-0.2860 \\
(0.0742)\end{array}$ & $* * *$ & $\begin{array}{l}-0.3010 \\
(0.0823)\end{array}$ & $* * *$ & $\begin{array}{l}-0.3212 \\
(0.0903)\end{array}$ & $* * *$ \\
\hline $\begin{array}{l}\text { Host Country Bank } \\
\text { Entry Requirements }\end{array}$ & $\begin{array}{l}-0.0874 \\
(0.0395)\end{array}$ & $* *$ & $\begin{array}{l}-0.0835 \\
(0.0383)\end{array}$ & ** & $\begin{array}{l}-0.0926 \\
(0.0403)\end{array}$ & $* *$ & $\begin{array}{l}-0.1009 \\
(0.0742)\end{array}$ & $* *$ & $\begin{array}{l}-0.0943 \\
(0.0390)\end{array}$ & $* *$ & $\begin{array}{l}-0.0963 \\
(0.0400)\end{array}$ & $* *$ \\
\hline $\begin{array}{l}\text { Host Country Restrictions } \\
\text { on Bank Activities }\end{array}$ & $\begin{array}{l}-0.0402 \\
(0.0206)\end{array}$ & $* *$ & $\begin{array}{l}-0.0500 \\
(0.0200)\end{array}$ & ** & $\begin{array}{l}-0.0453 \\
(0.0216)\end{array}$ & $* *$ & $\begin{array}{l}-0.0834 \\
(0.0227)\end{array}$ & $* * *$ & $\begin{array}{l}-0.0377 \\
(0.0211)\end{array}$ & * & $\begin{array}{l}-0.0431 \\
(0.0233)\end{array}$ & * \\
\hline $\begin{array}{l}\text { Host Country } \\
\text { Corporate Taxes }\end{array}$ & $\begin{array}{l}-0.0089 \\
(0.0060)\end{array}$ & & $\begin{array}{l}-0.0082 \\
(0.0059)\end{array}$ & & $\begin{array}{l}-0.0096 \\
(0.0060)\end{array}$ & & $\begin{array}{l}-0.0097 \\
(0.0057)\end{array}$ & * & $\begin{array}{l}-0.0082 \\
(0.0062)\end{array}$ & & $\begin{array}{l}-0.0090 \\
(0.0065)\end{array}$ & \\
\hline Host Country Size & $\begin{array}{c}0.2838 \\
(0.0512)\end{array}$ & $* * *$ & $\begin{array}{c}0.2901 \\
(0.0487)\end{array}$ & $* * *$ & $\begin{array}{c}0.2710 \\
(0.0497)\end{array}$ & $* * *$ & $\begin{array}{c}0.2542 \\
(0.0449)\end{array}$ & $* * *$ & $\begin{array}{c}0.2762 \\
(0.0538)\end{array}$ & $* * *$ & $\begin{array}{c}0.2674 \\
(0.0527)\end{array}$ & $* * *$ \\
\hline Host Country GDP per capita & $\begin{array}{c}0.0610 \\
(0.0135)\end{array}$ & $* * *$ & $\begin{array}{c}0.0460 \\
(0.0129)\end{array}$ & $* * *$ & $\begin{array}{c}0.0672 \\
(0.0146)\end{array}$ & $* * *$ & $\begin{array}{c}0.0435 \\
(0.0126)\end{array}$ & $* * *$ & $\begin{array}{c}0.0593 \\
(0.0131)\end{array}$ & $* * *$ & $\begin{array}{c}0.0655 \\
(0.0172)\end{array}$ & $* * *$ \\
\hline $\begin{array}{l}\text { Host Country Risk } \\
\text { (Composite index) }\end{array}$ & $\begin{array}{c}0.0005 \\
(0.0058)\end{array}$ & & & & & & & & & & & \\
\hline Host Country Political Risk & & & $\begin{array}{l}-0.0124 \\
(0.0057)\end{array}$ & & & & $\begin{array}{l}-0.0334 \\
(0.0112)\end{array}$ & & & & & \\
\hline Host Country Economical Risk & & & & & $\begin{array}{c}0.0163 \\
(0.0133)\end{array}$ & & $\begin{array}{c}0.0607 \\
(0.0248)\end{array}$ & $* *$ & & & $\begin{array}{c}0.0138 \\
(0.0174)\end{array}$ & \\
\hline Host Country Investment Risk & & & & & & & & & $\begin{array}{c}0.0292 \\
(0.0324)\end{array}$ & & $\begin{array}{c}0.0181 \\
(0.0414)\end{array}$ & \\
\hline Bilateral Trade & $\begin{array}{c}54.2008 \\
(14.3250)\end{array}$ & $* * *$ & $\begin{array}{c}49.4552 \\
(14.5934)\end{array}$ & $* * *$ & $\begin{array}{c}56.0415 \\
(13.9467)\end{array}$ & $* * *$ & $\begin{array}{c}48.8543 \\
(14.6448)\end{array}$ & $* * *$ & $\begin{array}{c}57.7539 \\
(15.5865) *\end{array}$ & $* * *$ & $\begin{array}{c}58.1011 \\
(15.5081)\end{array}$ & $* * *$ \\
\hline Dummy for Colonial Ties & $\begin{array}{c}0.3832 \\
(0.2008)\end{array}$ & * & $\begin{array}{c}0.4338 \\
(0.1987)\end{array}$ & ** & $\begin{array}{c}0.4258 \\
(0.1886)\end{array}$ & $* *$ & $\begin{array}{c}0.6739 \\
(0.1777)\end{array}$ & $* * *$ & $\begin{array}{c}0.3500 \\
(0.1993)\end{array}$ & * & $\begin{array}{c}0.3984 \\
(0.2074)\end{array}$ & $*$ \\
\hline Bilateral Distance & $\begin{array}{l}-0.2058 \\
(0.0412)\end{array}$ & $* * *$ & $\begin{array}{l}-0.2081 \\
(0.0415)\end{array}$ & $* * *$ & $\begin{array}{l}-0.2085 \\
(0.0419)\end{array}$ & $* * *$ & $\begin{array}{l}-0.2230 \\
(0.0442)\end{array}$ & $* * *$ & $\begin{array}{l}-0.2036 \\
(0.0407)\end{array}$ & $* * *$ & $\begin{array}{l}-0.2067 \\
(0.0423)\end{array}$ & $* * *$ \\
\hline Dummy for Common Language & $\begin{array}{c}1.0943 \\
(0.4860)\end{array}$ & $* *$ & $\begin{array}{l}1.0459 \\
(0.4823)\end{array}$ & $* *$ & $\begin{array}{l}1.0612 \\
(0.4765)\end{array}$ & $* *$ & $\begin{array}{c}0.8487 \\
(0.4464)\end{array}$ & * & $\begin{array}{c}1.1315 \\
(0.4810)\end{array}$ & $* *$ & $\begin{array}{c}1.0904 \\
(0.4766)\end{array}$ & $* *$ \\
\hline Dummy for Common Legal Origin & $\begin{array}{c}0.1833 \\
(0.1374)\end{array}$ & & $\begin{array}{c}0.1955 \\
(0.1363)\end{array}$ & & $\begin{array}{c}0.1770 \\
(0.1394)\end{array}$ & & $\begin{array}{c}0.1891 \\
(0.1380)\end{array}$ & & $\begin{array}{c}0.1777 \\
(0.1349)\end{array}$ & & $\begin{array}{c}0.1739 \\
(0.1369)\end{array}$ & \\
\hline Latin America Dummy & $\begin{array}{c}0.6948 \\
(0.2333)\end{array}$ & $* * *$ & $\begin{array}{c}0.7819 \\
(0.2390)\end{array}$ & $* * *$ & $\begin{array}{c}0.7274 \\
(0.2501)\end{array}$ & $* * *$ & $\begin{array}{c}1.0326 \\
(0.2806)\end{array}$ & $* * *$ & $\begin{array}{c}0.6563 \\
(0.2523)\end{array}$ & $* * *$ & $\begin{array}{c}0.6981 \\
(0.2813)\end{array}$ & $* *$ \\
\hline
\end{tabular}

This table reports the first stage of Heckman probit regressions with standard error adjusted for clustering on each parent bank. A constant is estimated but not reported. Robust Standard Errors are in parentheses. ${ }^{*},{ }^{* *}, * * *$ mean significance at ten, five and one percent, respectively. 
Table 8: $2^{\text {nd }}$ Stage Heckman Probit Estimations of the Likelihood that a Foreign Bank Operates as a Branch

\begin{tabular}{|c|c|c|c|c|c|c|c|c|c|}
\hline \multirow[b]{2}{*}{ Independent Variables } & \multicolumn{9}{|c|}{ Dependent variable: Branch=1 ; Sudsidiary=0 } \\
\hline & Model (1) & Model (2) & Model (3) & Model ( & & Model (5 & & Model & (6) \\
\hline $\begin{array}{l}\text { Parent Bank } \\
\text { Internationalization Strategy }\end{array}$ & $\begin{array}{l}3.2160 \\
(1.2502) \quad * * *\end{array}$ & $\begin{array}{c}3.2230 \\
(1.2967) \quad * *\end{array}$ & \begin{tabular}{cc|}
3.2421 & \\
$(1.2078)$ & $* * *$
\end{tabular} & $\begin{array}{c}3.2084 \\
(1.2724)\end{array}$ & $* *$ & $\begin{array}{c}3.3690 \\
(1.3432)\end{array}$ & ** & $\begin{array}{c}3.3797 \\
(1.3170)\end{array}$ & $* * *$ \\
\hline Parent Bank Size & $\begin{array}{l}-0.4110 \\
(0.2771)\end{array}$ & $\begin{array}{l}-0.4652 \\
(0.2849)\end{array}$ & \begin{tabular}{l|}
-0.3074 \\
$(0.2625)$
\end{tabular} & $\begin{array}{l}-0.3713 \\
(0.2831)\end{array}$ & & $\begin{array}{l}-0.4571 \\
(0.2854)\end{array}$ & & $\begin{array}{l}-0.3539 \\
(0.2852)\end{array}$ & \\
\hline $\begin{array}{l}\text { Parent Bank } \\
\text { Bussines Orientation }\end{array}$ & $\begin{array}{c}0.6845 \\
(0.5168)\end{array}$ & $\begin{array}{c}0.7545 \\
(0.5189) \\
\end{array}$ & $\begin{array}{l}-0.8079 \\
(0.5242)\end{array}$ & $\begin{array}{c}0.4019 \\
(0.5463)\end{array}$ & & $\begin{array}{c}0.6243 \\
(0.5179)\end{array}$ & & $\begin{array}{c}0.4405 \\
(0.5296)\end{array}$ & \\
\hline $\begin{array}{l}\text { Home Country Regulations } \\
\text { on Overseas Branches }\end{array}$ & $\begin{array}{l}-0.7395 \\
(0.3027) \quad * * \\
\end{array}$ & $\begin{array}{ll}-0.7421 & \\
(0.2956) \quad * * \\
\end{array}$ & $\begin{array}{|ll|}-0.8079 & \\
(0.2985) & * * * \\
\end{array}$ & $\begin{array}{l}-0.8296 \\
(0.3024) \\
\end{array}$ & $* * *$ & $\begin{array}{l}-0.6977 \\
0.2952 \\
\end{array}$ & $* *$ & $\begin{array}{l}-0.7571 \\
(0.3064) \\
\end{array}$ & $* *$ \\
\hline Affiliate Bank Size & $\begin{array}{l}-0.2566 \\
(0.1492) *\end{array}$ & $\begin{array}{l}-0.2714 \\
(0.1652) *\end{array}$ & $\begin{array}{l}-0.2799 \\
(0.1450) * \\
\end{array}$ & $\begin{array}{l}-0.3131 \\
(0.1692) \\
\end{array}$ & * & $\begin{array}{l}-0.3021 \\
(0.1640) \\
\end{array}$ & * & $\begin{array}{c}-0.3184 \\
(0.1601) \\
\end{array}$ & $* *$ \\
\hline $\begin{array}{l}\text { Affiliate Bank } \\
\text { Bussines Orientation } \\
\end{array}$ & $\begin{array}{l}-0.8534 \\
(0.3514) \quad * * \\
\end{array}$ & $\begin{array}{l}-0.8832 \\
(0.3411) \quad * * * \\
\end{array}$ & \begin{tabular}{ll|}
-0.8816 & \\
$(0.3417)$ & $* * *$ \\
\end{tabular} & $\begin{array}{l}-0.9757 \\
(0.3212) \\
\end{array}$ & $* * *$ & $\begin{array}{l}-0.8341 \\
(0.3294) \\
\end{array}$ & $* *$ & $\begin{array}{c}-0.8464 \\
(0.3260) \\
\end{array}$ & $* * *$ \\
\hline Year of Entry & $\begin{array}{c}-0.0315 \\
0.0058 \quad * * *\end{array}$ & $\begin{array}{c}-0.0309 \\
0.0053\end{array}$ *** & \begin{tabular}{cc|}
-0.0347 & \\
0.0059 & $* * *$ \\
\end{tabular} & $\begin{array}{c}-0.0353 \\
0.0052\end{array}$ & $* * *$ & $\begin{array}{c}-0.0315 \\
0.0051\end{array}$ & $* * *$ & $\begin{array}{c}-0.0341 \\
0.0054\end{array}$ & $* * *$ \\
\hline Acquisition Dummy & $\begin{array}{ll}-1.5340 & \\
(0.3213) & * * * \\
\end{array}$ & $\begin{array}{ll}-1.5222 & \\
(0.3637) & * * * \\
\end{array}$ & $\begin{array}{|ll|}-1.8713 & \\
(0.4233) & * * * \\
\end{array}$ & $\begin{array}{l}-1.9131 \\
(0.4754)\end{array}$ & $* * *$ & $\begin{array}{l}-1.7945 \\
(0.4699)\end{array}$ & $* * *$ & $\begin{array}{l}-2.1198 \\
(0.5914) \\
\end{array}$ & $* * *$ \\
\hline $\begin{array}{l}\text { Host Country Regulations } \\
\text { on Foreign Bank Branches }\end{array}$ & $\begin{array}{c}-0.8294 \\
(0.3227) * * * \\
\end{array}$ & $\begin{array}{c}-0.4358 \\
(0.2475) * \\
\end{array}$ & $\begin{array}{c}-1.3662 \\
(0.3339) * * * \\
\end{array}$ & $\begin{array}{l}-0.7066 \\
(0.2964) \\
\end{array}$ & ** & $\begin{array}{l}-0.6061 \\
(0.2029) \\
\end{array}$ & $* * *$ & $\begin{array}{l}-1.1171 \\
(0.4360) \\
\end{array}$ & $* * *$ \\
\hline $\begin{array}{l}\text { Host Country Bank } \\
\text { Entry Requirements }\end{array}$ & $\begin{array}{r}-0.2727 \\
(0.1834) \\
\end{array}$ & $\begin{array}{c}-0.2181 \\
(0.1827) \\
\end{array}$ & $\begin{array}{c}-0.3974 \\
(0.1917) * * \\
\end{array}$ & $\begin{array}{l}-0.3247 \\
(0.2057)\end{array}$ & & $\begin{array}{l}-0.3482 \\
(0.2102)\end{array}$ & * & $\begin{array}{l}-0.4689 \\
(0.2174) \\
\end{array}$ & $* *$ \\
\hline $\begin{array}{l}\text { Host Country Restrictions } \\
\text { on Bank Activities }\end{array}$ & $\begin{array}{r}0.1196 \\
(0.1148) \\
\end{array}$ & $\begin{array}{c}0.1986 \\
(0.1149) * \\
\end{array}$ & $\begin{array}{r}0.0118 \\
(0.1020) \\
\end{array}$ & $\begin{array}{c}0.1376 \\
(0.1236) \\
\end{array}$ & & $\begin{array}{c}0.1647 \\
(0.1172) \\
\end{array}$ & & $\begin{array}{c}0.0542 \\
(0.1328) \\
\end{array}$ & \\
\hline $\begin{array}{l}\text { Host Country } \\
\text { Corporate Taxes }\end{array}$ & $\begin{array}{c}0.0694 \\
(0.0241) * * *\end{array}$ & $\begin{array}{c}0.0573 \\
(0.0196) * * *\end{array}$ & $\begin{array}{c}0.1013 \\
(0.0308) * * * \\
\end{array}$ & $\begin{array}{c}0.0872 \\
(0.0235)\end{array}$ & $* * *$ & $\begin{array}{c}0.0886 \\
(0.0261) \\
\end{array}$ & & $\begin{array}{c}0.1175 \\
(0.0326)\end{array}$ & \\
\hline Host Country Size & $\begin{array}{r}-0.0451 \\
(0.1667) \\
\end{array}$ & $\begin{array}{r}-0.1664 \\
(0.1548) \\
\end{array}$ & $\begin{array}{r}0.0811 \\
(0.1187) \\
\end{array}$ & $\begin{array}{l}-0.1235 \\
(0.1176) \\
\end{array}$ & & $\begin{array}{l}-0.2008 \\
(0.1362) \\
\end{array}$ & & $\begin{array}{l}-0.0619 \\
(0.1424) \\
\end{array}$ & \\
\hline $\begin{array}{l}\text { Host Country GDP } \\
\text { per Capita }\end{array}$ & $\begin{array}{c}-0.4795 \\
(0.1312) * * *\end{array}$ & $\begin{array}{c}-0.3837 \\
(0.1340) * * * \\
\end{array}$ & $\begin{array}{c}-0.5337 \\
(0.1350) * * * \\
\end{array}$ & $\begin{array}{l}-0.2946 \\
(0.1326)\end{array}$ & $* *$ & $\begin{array}{l}-0.5906 \\
(0.1251) \\
\end{array}$ & & $\begin{array}{l}-0.6198 \\
(0.1384) \\
\end{array}$ & $* * *$ \\
\hline $\begin{array}{l}\text { Host Country Risk } \\
\text { (Composite index) }\end{array}$ & $\begin{array}{r}0.0025 \\
(0.0395) \\
\end{array}$ & & & & & & & & \\
\hline Host Country Political Risk & & $\begin{array}{r}0.0534 \\
(0.0357) \\
\end{array}$ & & $\begin{array}{c}0.1271 \\
(0.0383) \\
\end{array}$ & & & & & \\
\hline Host Country Economic Risk & & & $\begin{array}{c}-0.1174 \\
(0.0557) * * \\
\end{array}$ & $\begin{array}{l}-0.2240 \\
(0.0678) \\
\end{array}$ & $* * *$ & & & $\begin{array}{l}-0.1122 \\
(0.0654) \\
\end{array}$ & \\
\hline Host Country Investment Risk & & & & & & $\begin{array}{c}0.2775 \\
(0.1194) \\
\end{array}$ & & $\begin{array}{c}0.2555 \\
(0.1362) \\
\end{array}$ & \\
\hline Latin America Dummy & $\begin{array}{r}0.1288 \\
(0.3606) \\
\end{array}$ & $\begin{array}{r}0.0577 \\
(0.3582) \\
\end{array}$ & $\begin{array}{r}-0.1187 \\
(0.3936) \\
\end{array}$ & $\begin{array}{l}-0.5841 \\
(0.4308) \\
\end{array}$ & & $\begin{array}{c}0.3267 \\
(0.3972) \\
\end{array}$ & & $\begin{array}{c}0.0469 \\
(0.4585) \\
\end{array}$ & \\
\hline $\begin{array}{l}\text { Wald test of indep. eqns. } \\
(\mathrm{H} 0: \text { rho }=0)\end{array}$ & 0.0600 & 0.0900 & 0.0500 & 0.3500 & & 0.3400 & & 0.2400 & \\
\hline Prob > chi2 & 0.8141 & 0.7627 & 0.8262 & 0.5542 & & 0.5573 & & 0.6275 & \\
\hline Number of observation & 1933 & 1933 & 1933 & 1933 & & 1933 & & 1933 & \\
\hline Censored observations & 1693 & 1693 & 1693 & 1693 & & 1693 & & 1693 & \\
\hline Uncensored observations & 240 & 240 & 240 & 240 & & 240 & & 240 & \\
\hline
\end{tabular}

This table reports the second stage of Heckman probit regressions with standard error adjusted for clustering on each parent bank. A constant is estimated but not reported. Robust Standard Errors are in parentheses. *, **, *** mean significance at ten, five and one percent, respectively. See first stage estimation for more details 